\title{
The effects of heat stress in Italian Holstein dairy cattle
}

\author{
U. Bernabucci, ${ }^{*}$ S. Biffani, $†$ L. Buggiotti, ${ }^{*}$ A. Vitali, ${ }^{*}$ N. Lacetera, ${ }^{*}$ and A. Nardone ${ }^{* 1}$ \\ *Dipartimento di scienze e tecnologie per l'Agricoltura, le Foreste, la Natura e l'Energia (DAFNE), Università degli Studi della Tuscia, \\ 01100 Viterbo, Italy \\ †Associazione Nazionale Allevatori Frisona Italiana (ANAFI), 26100 Cremona, Italy
}

\section{ABSTRACT}

The data set for this study comprised 1,488,474 testday records for milk, fat, and protein yields and fat and protein percentages from 191,012 first-, second-, and third-parity Holstein cows from 484 farms. Data were collected from 2001 through 2007 and merged with meteorological data from 35 weather stations. A linear model (M1) was used to estimate the effects of the temperature-humidity index (THI) on production traits. Least squares means from M1 were used to detect the THI thresholds for milk production in all parities by using a 2-phase linear regression procedure (M2). A multiple-trait repeatability test-model (M3) was used to estimate variance components for all traits and a dummy regression variable (t) was defined to estimate the production decline caused by heat stress. Additionally, the estimated variance components and M3 were used to estimate traditional and heattolerance breeding values (estimated breeding values, EBV) for milk yield and protein percentages at parity 1. An analysis of data (M2) indicated that the daily THI at which milk production started to decline for the 3 parities and traits ranged from 65 to 76 . These THI values can be achieved with different temperature/ humidity combinations with a range of temperatures from 21 to $36^{\circ} \mathrm{C}$ and relative humidity values from 5 to $95 \%$. The highest negative effect of THI was observed $4 \mathrm{~d}$ before test day over the 3 parities for all traits. The negative effect of THI on production traits indicates that first-parity cows are less sensitive to heat stress than multiparous cows. Over the parities, the general additive genetic variance decreased for protein content and increased for milk yield and fat and protein yield. Additive genetic variance for heat tolerance showed an increase from the first to third parity for milk, protein, and fat yield, and for protein percentage. Genetic correlations between general and heat stress effects were all unfavorable (from -0.24 to -0.56 ). Three EBV per trait were calculated for each cow and bull (traditional

Received January 24, 2013.

Accepted September 18, 2013.

${ }^{1}$ Corresponding author: nardone@unitus.it
EBV, traditional EBV estimated with the inclusion of THI covariate effect, and heat tolerance EBV) and the rankings of EBV for 283 bulls born after 1985 with at least 50 daughters were compared. When THI was included in the model, the ranking for 17 and 32 bulls changed for milk yield and protein percentage, respectively. The heat tolerance genetic component is not negligible, suggesting that heat tolerance selection should be included in the selection objectives.

Key words: dairy cow, temperature-humidity index breaking point, production trait, heritability

\section{INTRODUCTION}

Heat stress can be simply defined as a condition that occurs when an animal cannot dissipate an adequate quantity of heat, whether it is produced or absorbed by the body, to maintain body thermal balance. This may prompt physiological and behavioral responses, leading to physiological disorders that negatively affect the productive and reproductive performance of farm animals (West, 2003; Nardone et al., 2006; 2010).

To study heat stress in livestock, the temperaturehumidity index (THI) is a commonly used bioclimatic index (Hahn et al., 2003). The THI is expressed as a single value representing the combined effects of air temperature and humidity, which is commonly used to evaluate the degree of heat stress in dairy cattle (NOAA, 1976; Armstrong, 1994). Bohmanova et al. (2007) compared 7 THI formulas and concluded that humidity was the limiting heat stress factor in humid climates, whereas the dry bulb temperature was the limiting factor for heat tolerance in dry climates.

Heat stress in warm environments is one of the major factors that can negatively affect milk production, reproduction, and the health of dairy cows (Jordan, 2003; Bernabucci et al., 2010). It is traditionally believed that milk synthesis begins to decrease when the THI reaches 72 (Johnson, 1985; du Preez et al., 1990; Armstrong, 1994). Recent data from the University of Arizona indicates that high-yielding dairy cows reduce their milk yield at a THI of approximately 68 (Zimbelman et al., 2009). Cattle become more sensitive to thermal stress as milk production increases (Kadzere et 
al., 2002). In fact, increasing daily milk yield from 35 to $45 \mathrm{~L} /$ cow per day is thought to increase sensitivity to thermal stress and reduces the threshold temperature by $5^{\circ} \mathrm{C}$ (Berman, 2005). This increased sensitivity is presumably explained by the extra heat associated with synthesizing additional milk.

Some authors (Collier et al., 1981; West, 2003; Spiers et al., 2004) reported that the THI of $2 \mathrm{~d}$ prior had the greatest effect on milk yield. However, the length and severity of the heat stress period and the point at which the THI starts to have a negative effect on production and reproduction have not been studied in depth. Establishing the length of the heat stress period, which influences production and reproduction, may represent an important factor in predicting the loss in yield and reproduction, and may assist in implementing adaptation measures.

Some studies have estimated the genetic components for both milk yield and reproduction traits under heat stress (Ravagnolo and Misztal, 2002a,b; Freitas et al., 2006; Aguilar et al., 2009), and they detected an unfavorable genetic relationship between THI and productive and reproductive traits. Those findings indicate that the intensive selection (especially for milk production traits) applied to dairy cows might have led to higher heat stress susceptibility in these animals. Thus, one strategy is to investigate the possibility of selecting dairy cattle for heat tolerance. The present study was based on data representing highly selected dairy cows to (a) identify the threshold point and time period when milk production starts to decline in the first 3 parities and (b) estimate the genetic parameters and breeding values of heat stress effects on milk production traits.

\section{MATERIALS AND METHODS}

\section{Data Set}

Data were provided by the Italian Holstein Breeders Association (Cremona, Italy) and comprised 1,488,474 test-day records from the first 3 parities of 191,012 Holstein cows. Records were collected from 484 farms and dated from 2001 through 2007. Italian Holstein cattle are an interesting case study because they represent a large and highly selected dairy cow population raised in the warm area of the Mediterranean Basin, which is becoming one of the hot spots in the world because of climate change (Segnalini et al., 2011).

Daily production traits comprising milk, fat, and protein yields and fat and protein percentages were recorded monthly and adhered to the International Committee for Animal Recording standards (http://www. icar.org/Documents/Rules\%20and\%20regulations/ Guidelines/Guidelines_2011.pdf).
The weather data included a minimum and a maximum for ambient temperatures and relative humidity and were obtained from 35 meteorological stations located within a maximum of $5 \mathrm{~km}$ from each herd, and the data consisted of daily weather information over a 7-yr period (2001-2007).

The THI was calculated by using the following formula (Vitali et al., 2009):

$$
\begin{aligned}
\mathrm{THI}= & (1.8 \times \mathrm{AT}+32)-(0.55-0.55 \times \mathrm{RH}) \\
& \times[(1.8 \times \mathrm{AT}+32)-58],
\end{aligned}
$$

where AT is the ambient temperature expressed in degrees, and $\mathrm{RH}$ is the relative humidity. With respect to the original equation, this formula includes the term $1.8 \times \mathrm{AT}+32$, which accounts for the conversion of temperature data from degrees Celsius to degrees Fahrenheit. This conversion was needed because most data in the literature reported the THI as being calculated by measuring ambient temperature on the Fahrenheit scale. A maximum AT and minimum $\mathrm{RH}$ were used for calculating the daily maximum THI. The maximum daily THI was chosen because it best fits data from public weather stations (Ravagnolo and Misztal, 2000), and because test-day milk yield is more sensitive to the extreme values of the maximum THI relative to the daily average THI (Brügemann et al., 2012). Production data were merged with weather information by assigning each test-day record to the daily weather records from the nearest weather station.

Age at calving classes were established for each parity according to the following thresholds: 20 to 36 (17 classes), 31 to 50 (20 classes), and 42 to 65 (24 classes) mo of age for first-, second-, and third-parity cows, respectively. Additionally, all cows were required to have at least first-lactation data and a minimum of 8 records per lactation (from 5 to 305 DIM). The DIM classes were defined as 1 class for every $30 \mathrm{~d}$, resulting in 11 classes. The weather data set was divided into $36 \mathrm{THI}$ classes, with the first class beginning at THI $=50$ and the subsequent classes were set at each 1 point THI thereafter until the last class, which had a THI $=85$.

After editing, the final data set consisted of 596,515 test-day records for 52,093 cows: 280,325 records for first parity (47\%), 192,702 records for second parity $(32 \%)$, and 123,489 records for third parity (21\%). The total number of records per THI class by parity is shown in Figure 1.

\section{Heat Stress Analysis Model}

The effect of THI (heat stress) on production traits was analyzed by fitting the following linear model (model 1): 


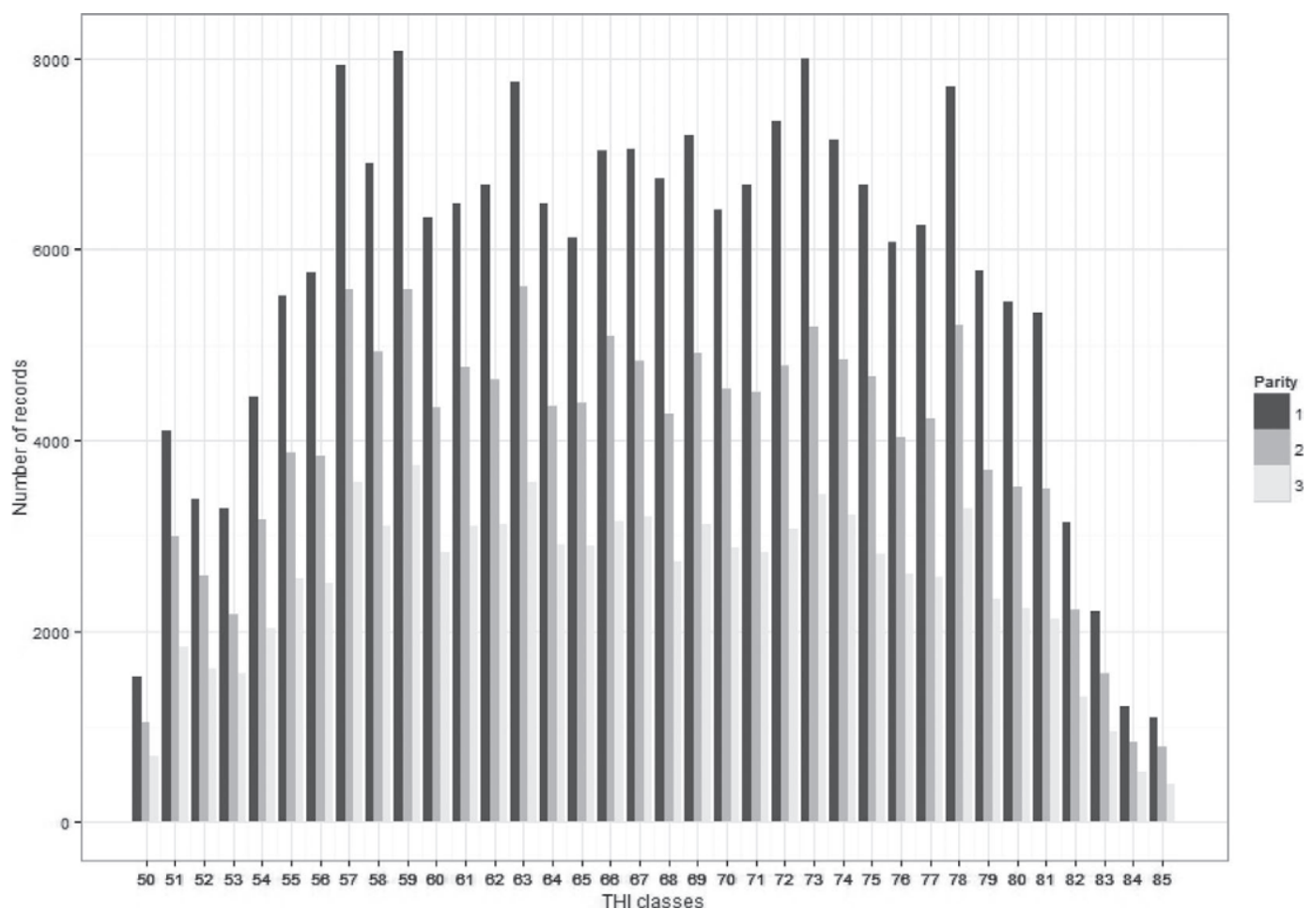

Figure 1. Total number of records per temperature-humidity index (THI) class by parity. Black bars = parity 1 ; dark gray bars $=$ parity 2 ; light gray bars $=$ parity 3 .

$$
\begin{gathered}
Y_{i j k l m n}=\operatorname{herd}(y c)_{i}+m c(y c)_{j}+c \operatorname{dim}_{k}+\text { thir }_{l}+\operatorname{age}_{m} \\
+\operatorname{ord}_{n}+\operatorname{thir}_{l} \times \operatorname{ord}_{n}+\operatorname{cdim}_{k} \times \operatorname{ord}_{n}+e_{i j k l m n},
\end{gathered}
$$

where $Y_{i j k l m n}$ is a measurement of milk yield and fat and protein (yield and \%); herd $(y c)_{i}$ is the fixed effect of the herd nested within the year of calving $(y c) i ; m c(y c)_{j}$ is the fixed effect of the month of calving $(m c)$ nested within the year of calving $j$; cdim $k$ is the fixed effect of DIM class $k$; thir $r_{l}$ is the fixed effect of THI class $l$; age a $_{m}$ is the fixed effect of age class $m$; $\operatorname{ord}_{n}$ is the fixed effect of parity $n$; thir ${ }_{l} \times \operatorname{ord}_{n}$ is the fixed effect of the THI class $l$ by parity class $n$; $\operatorname{cdim}_{k} \times \operatorname{ord}_{n}$ is the fixed effect of the DIM class $k$ by parity class $n$; and $e_{i j k l m n}$ is the random residual effect.

A minimum of 24 records per herd-year of calving were used and THI values were computed on the day of recording. All the analyses were conducted with PROC MIXED of SAS (version 9.1; SAS Institute, 2002).

In addition to the effects of the weather conditions on the day of milk recording, the effect of the THI for each of the $16 \mathrm{~d}$ before the test-day record was investigated for the milk, fat, and protein yields, and on the fat and protein percentages. A range of $16 \mathrm{~d}$ was an arbitrary choice based on the hypothesis that this period is sufficiently long to estimate the length in which the productive traits are significantly affected by the THI.

\section{Detection of Heat Stress Threshold}

The relationship between an environmental parameter (e.g., THI) and the response to that parameter (e.g., milk production) might be characterized by abrupt changes that cannot be correctly detected by a simple graphical inspection or by a standard linear regression. Therefore, a 2-phase linear regression procedure was applied to least squares means from model 1 to detect the exact THI at which milk yields and fat and protein (yields and percentages) started to decline (Nickerson et al., 1989). The following model (model 2) was used:

$$
\mathbf{y}_{i}=\mathbf{x}_{i}^{T} \boldsymbol{\beta}+\mathbf{u}_{i}(i=1, \ldots, n),
$$

where at time $i, \mathbf{y}_{i}$ is an observation of the dependent variable (e.g., least squared means of production), $\mathbf{x}_{i}^{T}$ is a $k \times 1$ vector of regressors, with the first component usually equal to unity; $\boldsymbol{\beta}$ is the $k \times 1$ vector of regression coefficients, which may vary over time (THI); and $\mathbf{u}_{i}$ are $i i d\left(0, \sigma^{2}\right)$ (i.e., $\mathbf{u}_{i}$ is a $k \times 1$ vector of residuals, which are independent and identically distributed with mean 0 and standard deviation $\sigma^{2}$ ).

The basic idea behind a 2-phase linear regression is testing the hypothesis that the regression coefficients remain constant (reduced model): 


$$
H_{0}: \boldsymbol{\beta}_{i}=\boldsymbol{\beta}_{0}(i=1, \ldots, n),
$$

compared with the alternative hypothesis that at least 1 coefficient varies over time (complete model). If the increase in the sum of square errors from the complete to the reduced model is significantly large, then the null hypothesis $\left(H_{0}\right)$ can be rejected, concluding that the complete model works well and a significant breaking point does exist (i.e., a significant change in production due to THI has been detected).

Moreover, because one of the aims of this study was to investigate the duration of heat stress, the analyses were repeated by regressing the least squares means on the THI for each of the $16 \mathrm{~d}$ before the test-day record. Finally, if the model detected any significant breaking point $(P<0.001)$, it was retained and a weighted average was calculated for each trait. The $\mathrm{R}$ software (http://cran.r-project.org) and the strucchange package (Zeileis et al., 2002) were used for all the analyses.

\section{Model for Variance Components and Breeding Value Estimation}

The model used to estimate variance components was a multiple-trait repeatability test-day model, which considered multiple lactations as different traits (model 3). A dummy regression variable ( $\mathrm{t}$ ) was defined and included in the model to estimate the decline in production from heat stress. If the observed THI was below a particular THI threshold, a value of 0 was assigned to the variable $t$ (i.e., no heat stress), and if the observed THI was above the threshold, variable $t$ was the difference between the observed THI and that particular threshold.

A different threshold was used for each parity and trait (Table 1). The thresholds were obtained by averaging the THI values $8 \mathrm{~d}$ before the test day for milk yield and $12 \mathrm{~d}$ before the test day for milk characteristics (proteins and fat). Model 3 is as follows:

$$
\begin{gathered}
Y_{i j k l m n o}=h t d_{i j}+d i m_{k}+\operatorname{age}_{j m}+m c_{l}(y c)_{n m}+a_{j o} \\
+v_{j o}\left[\mathrm{f}(\mathrm{THI})_{i}\right]+p_{j o}+q_{j o}\left[\mathrm{f}(\mathrm{THI})_{i}\right]+e_{i j k l m n o}
\end{gathered}
$$

where $Y_{i j k l m n o}$ is a measurement of milk, fat, and protein yields, and the protein percentage for cow $o$ in age class $m$ within parity $j(1,2$, or 3$)$ and DIM class $k$ for herd test-day $i$ within parity $j$ and month of calving $l$ nested within year of calving $m$ within parity $j ; h t d_{i j}$ is the fixed effect of the herd test-day $i$ within parity $j$; $\operatorname{dim}_{k}$ is the fixed effect of the DIM class $k$; age $\mathrm{j}_{m}$ is the fixed effect of age class; $m c_{l}(y c)_{n m}$ is the fixed effect of the month of calving nested within the year of calving; $a_{j o}$ is the effect of the additive genetic merit of cow $o$ within the parity $j ; v_{j o}$ is the additive effect of the heat tolerance of cow $o$ within parity $j ; p_{j o}$ is the permanent environmental effect of cow $o$ within parity $j ; q_{j o}$ is the permanent environmental effect of the heat tolerance of cow $o$ within parity $j$; and $e_{i j k l m n o}$ is the residual.

Let $\mathbf{a}^{\prime}=\left[\begin{array}{ll}a_{j o}^{\prime} & v_{j o}\end{array}\right]$ be the vector of random additive genetic effects and $\mathbf{p}^{\prime}=\left[\begin{array}{ll}p^{\prime}{ }_{j o} & q_{j o}\end{array}\right]$ be the vector of random permanent environmental effects for parities $j$ $=1$ to 3 . The (co)variance structure was as follows:

$$
\operatorname{Var}\left[\begin{array}{l}
a \\
p \\
e
\end{array}\right]=\left[\begin{array}{ccc}
\mathbf{A} \otimes \mathbf{G}_{\mathbf{0}} & 0 & 0 \\
0 & \mathbf{I} \otimes \mathbf{P}_{\mathbf{0}} & 0 \\
0 & 0 & \mathbf{I} \otimes \mathbf{R}_{\mathbf{0}}
\end{array}\right],
$$

where $\mathbf{A}$ is the numerator relationship matrix; $\mathbf{I}$ is the identity matrix; $\mathbf{G}_{\mathbf{0}}$ and $\mathbf{P}_{\mathbf{0}}$ are $6 \times 6$ matrices of (co) variances for additive and permanent environmental effects, respectively; and $\mathbf{R}_{0}$ is a diagonal matrix of residual variances corresponding to each trait.

A minimum of 10 records per herd-year of calving (model 3) and 30 daughters per sire were required to estimate variance components. Statistics on the number of records and animals included in the analyses and means and the standard deviations for all traits considered are presented in Tables 2 and 3.

Multiple-trait analyses were performed for all traits by using GIBBS1F90 software (http://nce.ads.uga. $\mathrm{edu} / \mathrm{html} /$ projects/programs/Linux/32bit/gibbs1f90). This software implements Gibbs sampling with a joint sampling of random correlated effects and traits (Misztal et al., 2002; Aguilar et al., 2009). A single chain of 300,000 samples was run for each trait/model, with the first 50,000 samples discarded as burn-ins. Additive genetic, permanent environmental, and phenotypic variances and heritability estimates were calculated by using the remaining 250,000 samples. The convergence of the chains was determined by visual inspection of the trace plots for the parameters of major interest.

To estimate the effect of THI on genetic evaluations and bull ranking, the estimated variance components and model 3 were used to analyze the entire data set, which comprised 8,859 sires and 144,446 cows and was used to calculate traditional and heat-tolerance breeding values (EBV) for milk yield and protein percentage in parity 1 . Breeding values were estimated by using the BLUPF90 program (Misztal et al., 2002).

Traditional EBV describe the genetic potential for milk production under thermal-neutral conditions, whereas heat stress EBV describe the genetic potential for milk production under hot conditions. Two analyses were run for each trait, including or not including the THI covariate effect. For simplicity, the following notation will be used through the text: traditional EBV 
Table 1. Estimated weighted average daily maximum temperature-humidity index (THI) from the breaking point analysis at $8 \mathrm{~d}$ before the test day for milk yield and $12 \mathrm{~d}$ before the test day for milk characteristics (protein and fat)

\begin{tabular}{|c|c|c|c|c|c|c|c|c|c|c|c|c|c|c|c|c|}
\hline \multirow[b]{2}{*}{ Trait } & \multirow[b]{2}{*}{ Parity } & \multirow{2}{*}{$\begin{array}{l}\text { THI } \\
\text { breaking } \\
\text { point } \\
\text { analysis }^{1}\end{array}$} & \multicolumn{13}{|c|}{ Days relative to test day } & \multirow{2}{*}{$\begin{array}{c}\text { Weightec } \\
\text { THI } \\
\text { breaking } \\
\text { points }\end{array}$} \\
\hline & & & -12 & -11 & -10 & -9 & -8 & -7 & -6 & -5 & -4 & -3 & -2 & -1 & 0 & \\
\hline \multirow{8}{*}{$\begin{array}{l}\text { Milk yield, } \\
\mathrm{kg} / \mathrm{d}\end{array}$} & 1 & THI & & & & & 76 & 77 & 75 & 77 & 76 & 74 & 74 & 78 & 77 & \multirow[t]{3}{*}{76} \\
\hline & & $\mathrm{b}$ & & & & & $-0.52 \dagger$ & $-0.82 \ddagger$ & $-0.82 \ddagger$ & $-0.82 \ddagger$ & $-0.91 \ddagger$ & $-0.91 \dagger$ & $-0.75 \dagger$ & $-0.71 \ddagger$ & $-0.43^{*}$ & \\
\hline & & $\mathrm{R}^{2}$ & & & & & 0.64 & 0.79 & 0.72 & 0.83 & 0.75 & 0.61 & 0.60 & 0.78 & 0.52 & \\
\hline & 2 & THI & & & & & 74 & 72 & 73 & 72 & 76 & 74 & 72 & 74 & 75 & \multirow[t]{2}{*}{73} \\
\hline & & $\begin{array}{l}\mathrm{b} \\
\mathrm{R}^{2}\end{array}$ & & & & & $\begin{array}{c}-0.59 \dagger \\
0.64\end{array}$ & $\begin{array}{c}-0.69 \dagger \\
0.54\end{array}$ & $\begin{array}{c}-0.87 \dagger \\
0.58\end{array}$ & $\begin{array}{c}-0.87 \dagger \\
0.52\end{array}$ & $\begin{array}{c}-1.16 \ddagger \\
0.81\end{array}$ & $\begin{array}{c}-1.10 \dagger \\
0.60\end{array}$ & $\begin{array}{c}-0.86 \dagger \\
0.54\end{array}$ & $\begin{array}{c}-0.76 \dagger \\
0.58\end{array}$ & $\begin{array}{c}-0.56^{*} \\
0.40\end{array}$ & \\
\hline & 3 & THI & & & & & 76 & 75 & 73 & 76 & 76 & 72 & 70 & 74 & 74 & \multirow[t]{2}{*}{74} \\
\hline & & $\begin{array}{l}\mathrm{b} \\
\mathrm{R}^{2}\end{array}$ & & & & & $\begin{array}{c}-0.78 \ddagger \\
0.73\end{array}$ & $\begin{array}{c}-0.96 \ddagger \\
0.79\end{array}$ & $\begin{array}{c}-1.02 \ddagger \\
0.72\end{array}$ & $\begin{array}{c}-1.16 \ddagger \\
0.88\end{array}$ & $\begin{array}{c}-1.27 \ddagger \\
0.88\end{array}$ & $\begin{array}{c}-0.98 \dagger \\
0.58\end{array}$ & $\begin{array}{c}-0.85^{*} \\
0.49\end{array}$ & $\begin{array}{c}-0.89 \dagger \\
0.55\end{array}$ & $\begin{array}{c}-0.60^{*} \\
0.41\end{array}$ & \\
\hline & 1 & THI & 74 & 72 & 73 & 76 & 76 & 61 & 68 & 70 & 65 & 62 & 63 & 70 & 73 & \multirow[t]{3}{*}{65} \\
\hline & & $\mathrm{b}$ & $-0.02^{*}$ & $-0.02 \dagger$ & $-0.03 \dagger$ & $-0.03 \dagger$ & $-0.03 \dagger$ & $-0.03^{*}$ & $-0.04 \dagger$ & $-0.06 \ddagger$ & $-0.06 \ddagger$ & $-0.06 \ddagger$ & $-0.07 \ddagger$ & $-0.06 \dagger$ & $-0.07 \ddagger$ & \\
\hline & & $\mathrm{R}^{2}$ & 0.47 & 0.67 & 0.57 & 0.65 & 0.70 & 0.39 & 0.58 & 0.78 & 0.74 & 0.73 & 0.73 & 0.65 & 0.73 & \\
\hline & 2 & THI & 67 & 60 & 76 & 63 & 66 & 67 & 65 & 73 & 70 & 70 & 69 & 69 & 72 & \multirow[t]{3}{*}{69} \\
\hline & & $\mathrm{b}$ & $-0.04 \dagger$ & $-0.04^{*}$ & $-0.06 \ddagger$ & $-0.05 \dagger$ & $-0.05 \ddagger$ & $-0.06 \ddagger$ & $-0.06 \dagger$ & $-0.09 \ddagger$ & $-0.08 \ddagger$ & $-0.09 \ddagger$ & $-0.09 \dagger$ & $-0.10 \ddagger$ & $-0.10 \ddagger$ & \\
\hline & & $\mathrm{R}^{2}$ & 0.68 & 0.40 & 0.71 & 0.59 & 0.74 & 0.71 & 0.58 & 0.79 & 0.75 & 0.70 & 0.68 & 0.71 & 0.74 & \\
\hline & 3 & THI & 71 & 73 & 74 & 61 & 73 & 74 & 71 & 74 & 68 & 72 & 71 & 72 & 71 & \multirow[t]{3}{*}{71} \\
\hline & & $\mathrm{b}$ & $-0.05 \ddagger$ & $-0.05 \ddagger$ & $-0.05 \ddagger$ & $-0.05 \ddagger$ & $-0.06 \ddagger$ & $-0.08 \ddagger$ & $-0.08 \ddagger$ & $-0.09 \ddagger$ & $-0.09 \dagger$ & $-0.10 \ddagger$ & $-0.10 \ddagger$ & $-0.10 \ddagger$ & $-0.10 \ddagger$ & \\
\hline & & $\mathrm{R}^{2}$ & 0.76 & 0.80 & 0.78 & 0.45 & 0.81 & 0.75 & 0.77 & 0.79 & 0.67 & 0.73 & 0.73 & 0.73 & 0.71 & \\
\hline \multirow[t]{3}{*}{ Fat, $\%$} & 1 & THI & - & - & - & - & - & - & - & - & - & - & - & - & - & \multirow{4}{*}{$\begin{array}{c}\text { Absent } \\
\text { Absent } \\
\text { Absent } \\
72\end{array}$} \\
\hline & 2 & $\mathrm{~b}$ & - & - & - & - & - & - & - & - & - & - & - & - & - & \\
\hline & 3 & $\mathrm{R}^{2}$ & - & - & - & - & - & - & - & - & - & - & - & - & - & \\
\hline \multirow{8}{*}{$\begin{array}{l}\text { Protein yield, } \\
\mathrm{kg} / \mathrm{d}\end{array}$} & 1 & THI & 73 & 71 & 73 & 70 & 76 & 75 & 73 & 71 & 70 & 72 & 72 & 74 & 76 & \\
\hline & & $\mathrm{b}$ & $-0.01^{*}$ & $-0.01^{*}$ & $-0.01 \dagger$ & $-0.01^{*}$ & $-0.02 \ddagger$ & $-0.03 \ddagger$ & $-0.03 \dagger$ & $-0.03 \dagger$ & $-0.04 \ddagger$ & $-0.05 \ddagger$ & $-0.04 \ddagger$ & $-0.04 \dagger$ & $-0.03 \dagger$ & \\
\hline & & $\mathrm{R}^{2}$ & 0.36 & 0.38 & 0.68 & 0.38 & 0.78 & 0.76 & 0.67 & 0.61 & 0.80 & 0.74 & 0.75 & 0.67 & 0.71 & \\
\hline & 2 & THI & 70 & 67 & 74 & 74 & 69 & 68 & 71 & 70 & 76 & 73 & 72 & 74 & 74 & \multirow{2}{*}{72} \\
\hline & & $\mathrm{b}^{2}$ & $-0.02^{*}$ & $-0.02^{*}$ & $-0.03 \dagger$ & $-0.02^{*}$ & $-0.02 \dagger$ & $-0.04 \dagger$ & $-0.04 \dagger$ & $-0.04 \dagger$ & $-0.06 \ddagger$ & $-0.06 \dagger$ & $-0.05 \dagger$ & $-0.05 \ddagger$ & $-0.04 \dagger$ & \\
\hline & 3 & THI & 72 & 75 & 74 & 75 & 76 & 74 & 69 & 74 & 76 & 72 & 71 & 74 & 73 & 73 \\
\hline & & $\mathrm{b}$ & $-0.02^{*}$ & $-0.04 \ddagger$ & $-0.04 \ddagger$ & $-0.04 \ddagger$ & $-0.04 \ddagger$ & $-0.05 \ddagger$ & $-0.04 \dagger$ & $-0.06 \ddagger$ & $-0.07 \ddagger$ & $-0.06 \dagger$ & $-0.06 \dagger$ & $-0.06 \dagger$ & $-0.05 \dagger$ & \\
\hline & & $\mathrm{R}^{2}$ & 0.48 & 0.84 & 0.77 & 0.83 & 0.81 & 0.78 & 0.57 & 0.83 & 0.86 & 0.68 & 0.67 & 0.70 & 0.66 & \\
\hline \multirow{9}{*}{$\begin{array}{l}\text { Fat yield, } \\
\mathrm{kg} / \mathrm{d}\end{array}$} & 1 & THI & 74 & 73 & 76 & 70 & 72 & 74 & 75 & 73 & 70 & 71 & 72 & 75 & 73 & \multirow[t]{3}{*}{72} \\
\hline & & b & $-0.03 \dagger$ & $-0.02 \ddagger$ & $-0.03 \dagger$ & $-0.02 \dagger$ & $-0.03 \ddagger$ & $-0.05 \ddagger$ & $-0.05 \ddagger$ & $-0.05 \ddagger$ & $-0.05 \ddagger$ & $-0.05 \ddagger$ & $-0.04 \dagger$ & $-0.04 \ddagger$ & $-0.03 \dagger$ & \\
\hline & & $\mathrm{R}^{2}$ & 0.61 & 0.76 & 0.56 & 0.63 & 0.81 & 0.76 & 0.75 & 0.74 & 0.73 & 0.71 & 0.64 & 0.71 & 0.53 & \\
\hline & 2 & THI & 72 & 70 & 74 & 74 & 70 & 72 & 70 & 73 & 69 & 76 & 68 & 63 & 72 & \multirow[t]{3}{*}{71} \\
\hline & & b & $-0.03 \dagger$ & $-0.04 \dagger$ & $-0.05 \ddagger$ & $-0.05 \ddagger$ & $-0.04 \dagger$ & $-0.05 \dagger$ & $-0.05 \dagger$ & $-0.06 \ddagger$ & $-0.05 \ddagger$ & $-0.06 \ddagger$ & $-0.03 \dagger$ & $-0.03^{*}$ & $-0.04 \ddagger$ & \\
\hline & & $\mathrm{R}^{2}$ & 0.54 & 0.65 & 0.75 & 0.75 & 0.66 & 0.68 & 0.63 & 0.77 & 0.60 & 0.70 & 0.63 & 0.46 & 0.73 & \\
\hline & 3 & THI & 75 & 75 & 74 & 76 & 69 & 74 & 69 & 73 & 76 & 72 & 69 & 69 & 73 & \multirow{3}{*}{71} \\
\hline & & $\mathrm{b}$ & $-0.04 \dagger$ & $-0.05 \ddagger$ & $-0.05 \ddagger$ & $-0.05 \ddagger$ & $-0.04 \dagger$ & $-0.06 \ddagger$ & $-0.05 \dagger$ & $-0.06 \ddagger$ & $-0.07 \ddagger$ & $-0.06 \dagger$ & $-0.03 \dagger$ & $-0.03 \dagger$ & $-0.04 \dagger$ & \\
\hline & & $\mathrm{R}^{2}$ & 0.68 & 0.78 & 0.73 & 0.78 & 0.52 & 0.74 & 0.63 & 0.76 & 0.79 & 0.70 & 0.62 & 0.63 & 0.61 & \\
\hline
\end{tabular}


Table 2. Estimates of variance components and their posterior SD for milk yield and protein percentage

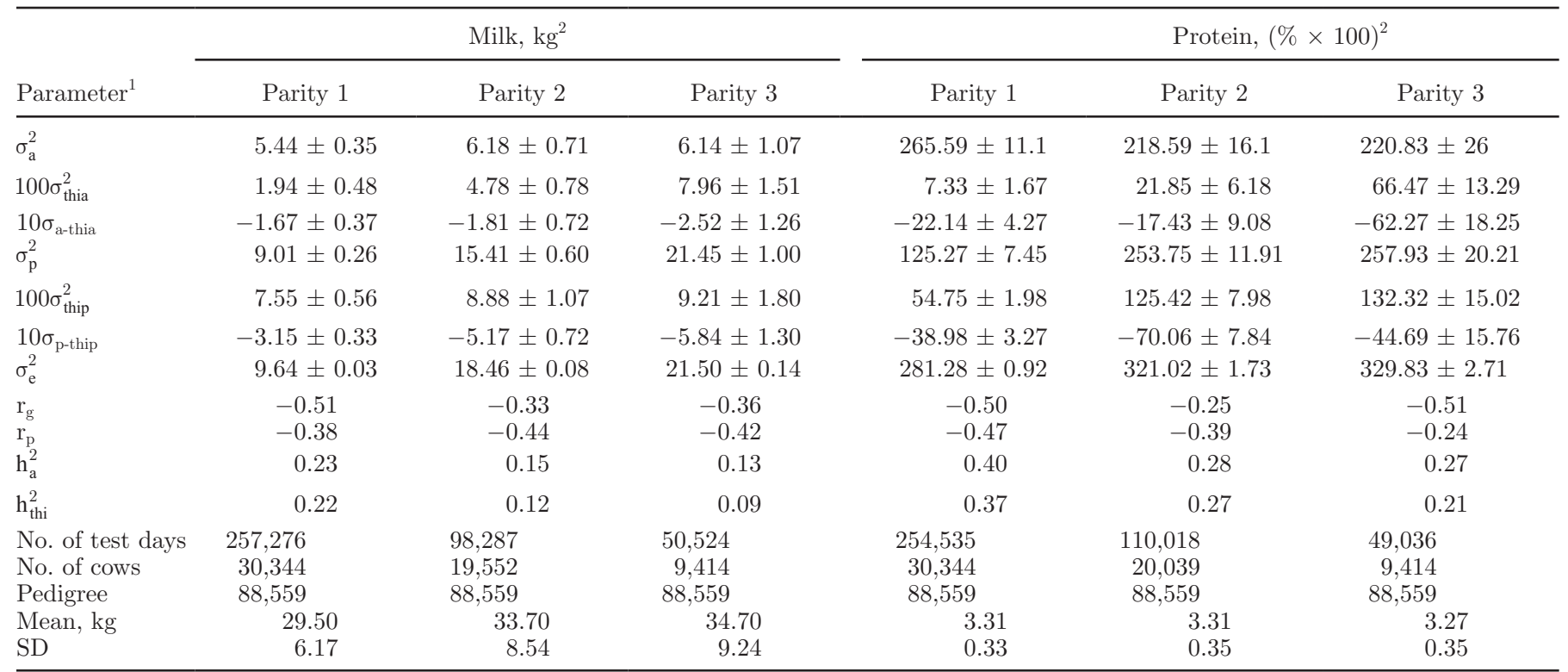

${ }^{1} \sigma_{\mathrm{a}}^{2}=$ additive genetic variance; $\sigma_{\text {thia }}^{2}=$ additive genetic variance for temperature-humidity index $(\mathrm{THI}) ; \sigma_{\mathrm{a}-\text { thia }}=$ additive genetic covariance between the general effect and the effect of THI; $\sigma_{\mathrm{p}}^{2}=$ permanent environmental variance; $\sigma_{\text {thip }}^{2}=$ permanent environmental THI variance; $\sigma_{\mathrm{p} \text {-thip }}$ $=$ additive genetic covariance between the permanent environmental effect and the effect of THI; $\sigma_{\mathrm{e}}^{2}=$ residual variance; $\mathrm{r}_{\mathrm{g}}=$ genetic correlation; $\mathrm{r}_{\mathrm{p}}=$ permanent environmental correlation; $\mathrm{h}_{\mathrm{a}}^{2}=$ general effect heritability; $\mathrm{h}_{\mathrm{thi}}^{2}=$ heat stress heritability.

for milk yield estimated without the inclusion of the for milk yield estimated with the inclusion of the THI THI covariate effect $\left(\mathbf{E B V}_{\mathbf{C}} \mathbf{M}\right)$, traditional EBV for covariate effect $\left(\mathbf{E B V} \_\mathbf{M w}\right)$, traditional EBV for proprotein percentage estimated without the inclusion of tein percentage estimated with the inclusion of the THI the THI covariate effect (EBV_PP), traditional EBV covariate effect (EBV_PPw), heat tolerance EBV

Table 3. Estimates of variance components and their posterior SD for protein and fat yields

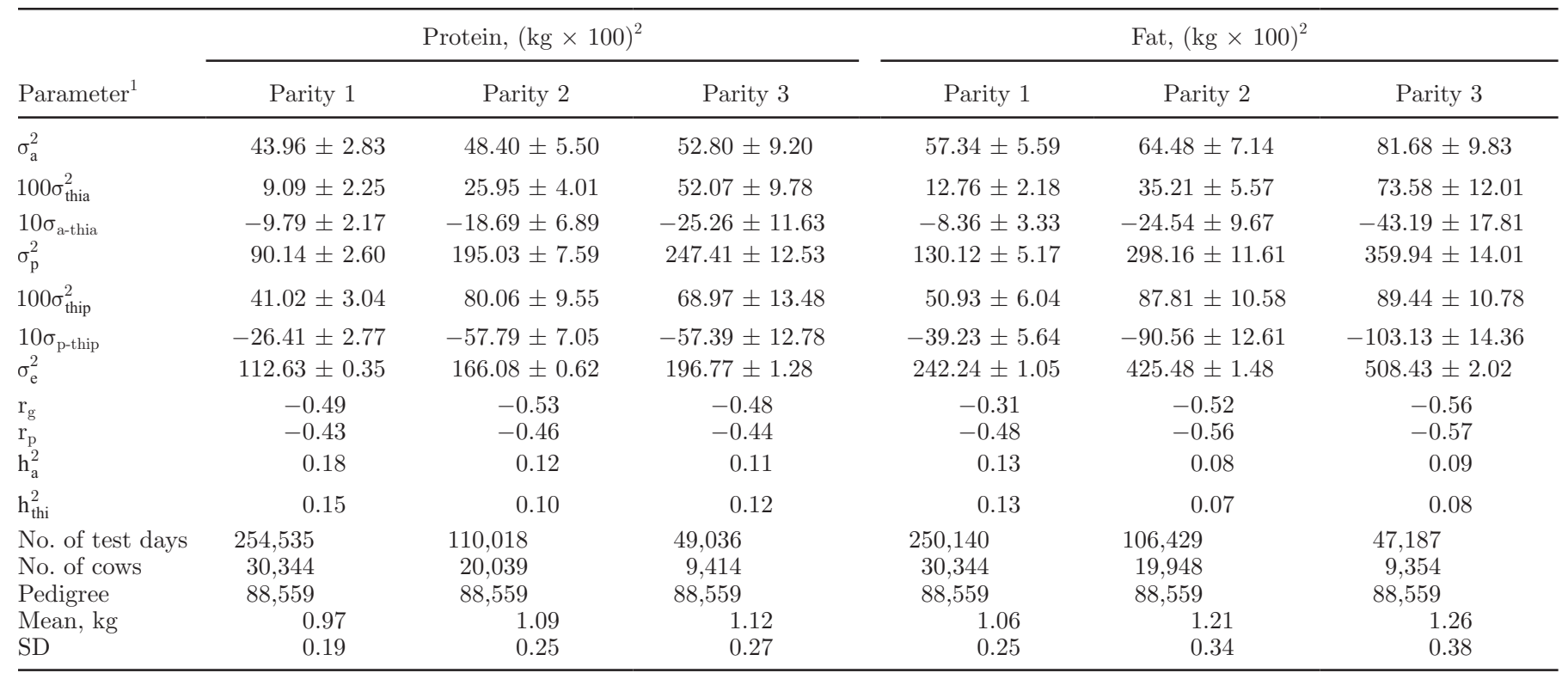

${ }^{1} \sigma_{\mathrm{a}}^{2}=$ additive genetic variance; $\sigma_{\text {thia }}^{2}=$ additive genetic variance for temperature-humidity index $(\mathrm{THI}) ; \sigma_{\mathrm{a} \text {-thia }}=$ additive genetic covariance between the general effect and the effect of THI; $\sigma_{\mathrm{p}}^{2}=$ permanent environmental variance; $\sigma_{\text {thip }}^{2}=$ permanent environmental THI variance; $\sigma_{\mathrm{p} \text {-thip }}$ $=$ additive genetic covariance between the permanent environmental effect and the effect of THI; $\sigma_{\mathrm{e}}^{2}=$ residual variance; $\mathrm{r}_{\mathrm{g}}=$ genetic correlation; $\mathrm{r}_{\mathrm{p}}=$ permanent environmental correlation; $\mathrm{h}_{\mathrm{a}}^{2}=$ general effect heritability; $\mathrm{h}_{\mathrm{thi}}^{2}=$ heat stress heritability. 


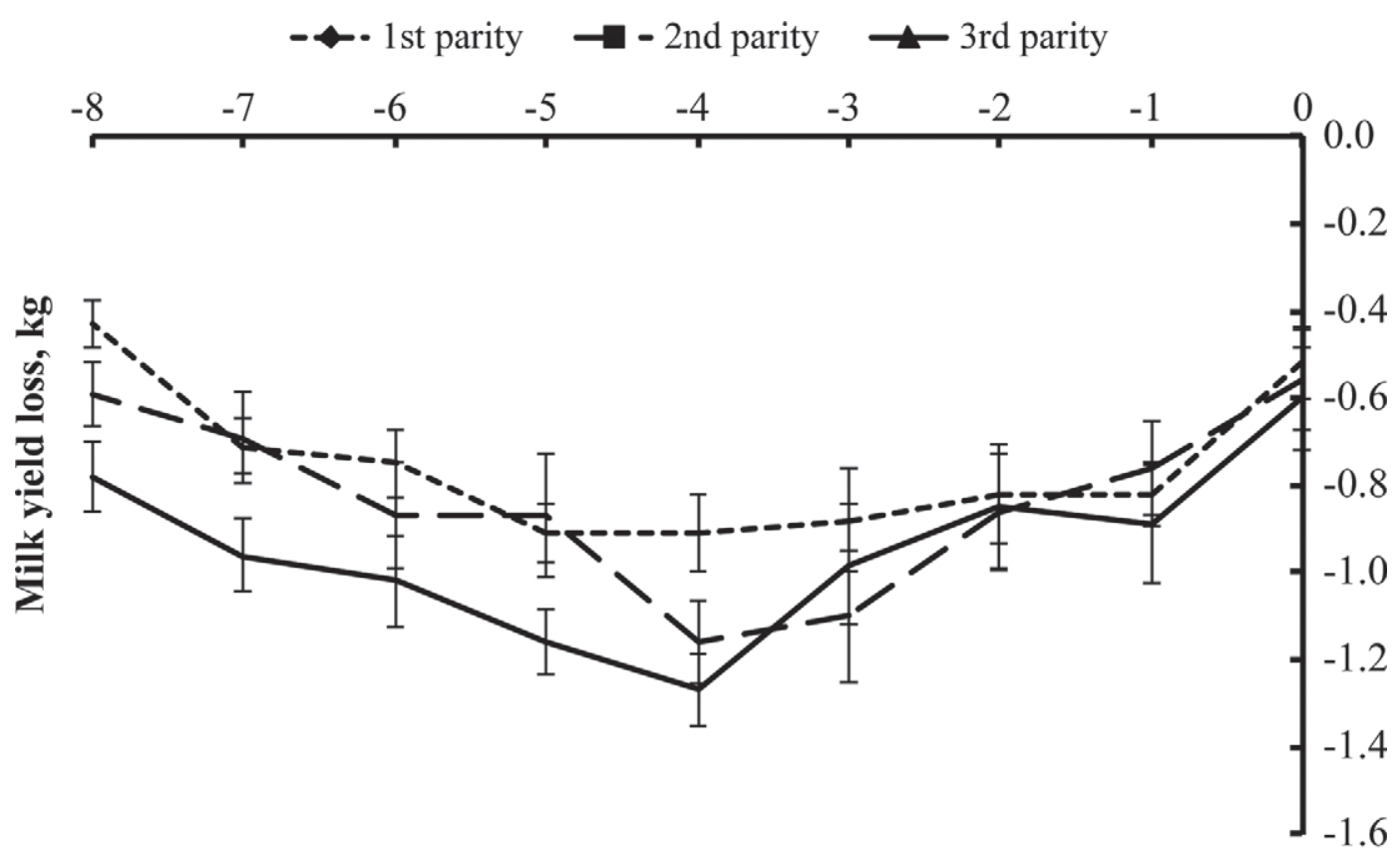

Day relative to test-day

Figure 2. Effect and duration of temperature-humidity index (THI) stress on milk production by parity [LSM ( \pm SD) loss pattern (kg/d)].

for milk yield (THI_M), and heat tolerance EBV for protein percentage (THI_PP).

Finally, bulls born after 1985 and having at least 50 daughters $(\mathrm{n}=283)$ were used to compare their rankings based on EBVs estimated with or without the inclusion of a THI covariate effect. To allow a direct and easy comparison of the results, all EBVs were expressed in genetic standard deviation units.

\section{RESULTS AND DISCUSSION}

\section{THI Breaking Points}

The milk yields were unfavorably affected by the THI starting from d 8 before the test day (Table 1; Figure 2 ). The highest negative effect was observed $4 \mathrm{~d}$ before the test day in all 3 parities. In particular, milk losses were as follows: $0.91,1.16$, and $1.27 \mathrm{~kg} / \mathrm{d}$ for the first, second, and third parity, respectively.

Considering the protein percentage and yield (Table 1; Figure 3a and 3b), the effect of THI was significant in all parities during a 12-d period before the test day. Daily protein losses ranged from -0.02 to $-0.10 \% / d$ and from -0.01 to $-0.07 \mathrm{~kg} / \mathrm{d}$. The reduction in milk protein (yield and percentage) was more affected by THI 3 to $4 \mathrm{~d}$ before the test day, and the highest losses were observed in the second and third parities compared with primiparous cows. Fat losses in kilograms (Table 1; Figure 4) ranged from -0.07 to $-0.02 \mathrm{~kg} / \mathrm{d}$, and the nadir for all parities was observed between 3 and $4 \mathrm{~d}$ before the test day.

West (2003) reported that under hot conditions, the milk yield was negatively affected by the THI as recorded 2 d before the control. Spiers et al. (2004) observed an increase in the respiration rate and rectal temperature $1 \mathrm{~d}$ after exposure to hot conditions and a reduction in the DMI and milk yield 2 to $4 \mathrm{~d}$ after hot exposure. Similarly, other authors (Collier et al., 1981) reported a greater effect on milk yield by temperatures recorded 24 or $48 \mathrm{~h}$ before the test day.

The THI has a persistent effect on all production traits ( 8 and 12 d before the test day for milk yield and milk characteristics, respectively), but the most significant effects were 3 to $4 \mathrm{~d}$ before the test day in all parities and for all traits (Table 1). Moreover, the time-period effect of THI on production traits shows that the first-parity cows had lower sensitivity to heat stress than multiparous cows (Figures 1, 2, and 3).

Least squares means were adjusted for the THI effect on milk, fat, and protein yields and fat and protein percentages for the first 3 parities and are shown in Figures 5 and 6 . All 3 parities showed similar trends, highlighting the negative effect of high THI on production traits. Weighted THI breaking points for production traits were estimated over a period of $8 \mathrm{~d}$ for the milk yield and $12 \mathrm{~d}$ for milk proteins and fat before the test day, as reported in Table 1. The weighted THI breaking points for the 3 parities ranged from 73 to 76 , 


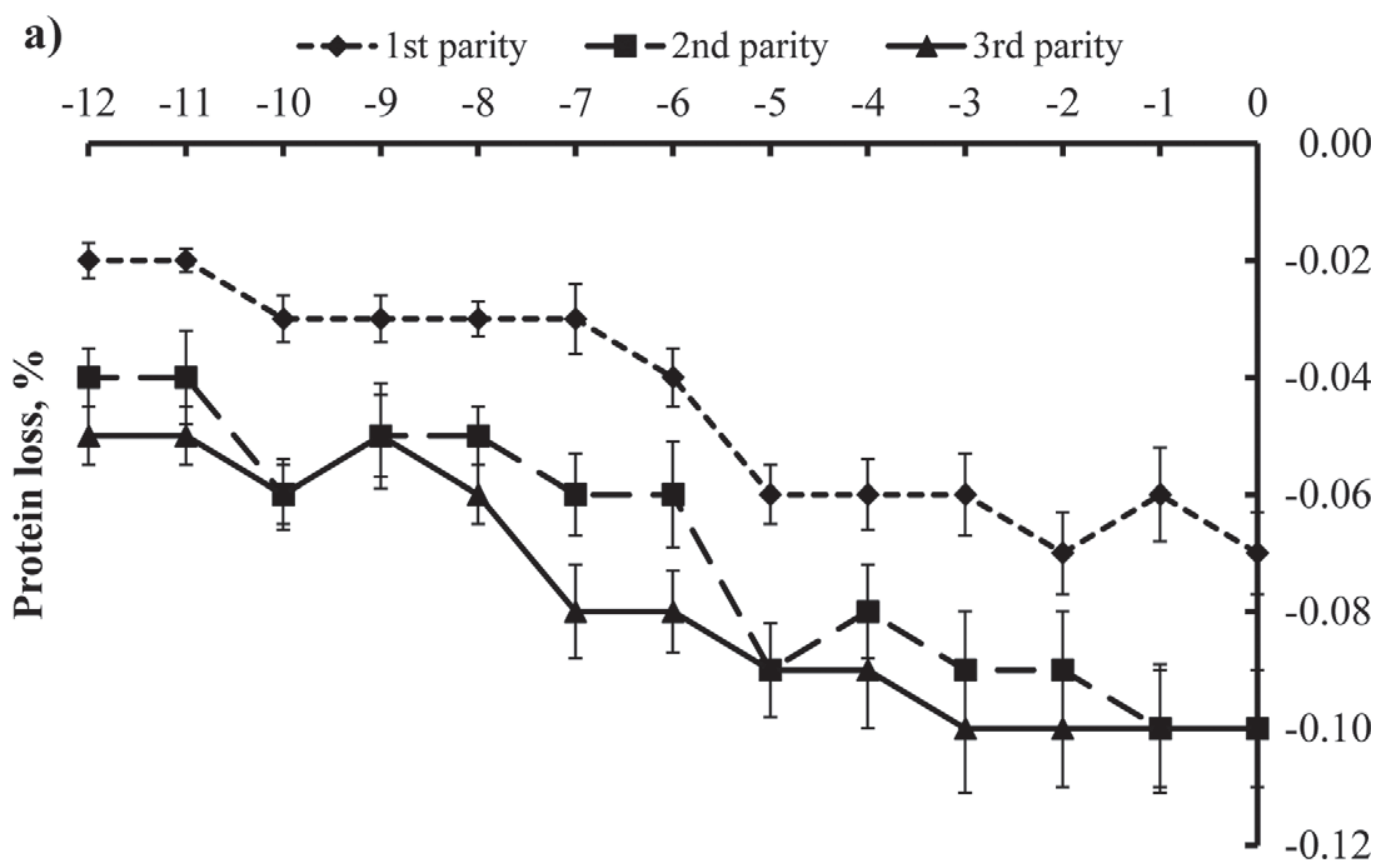

b)

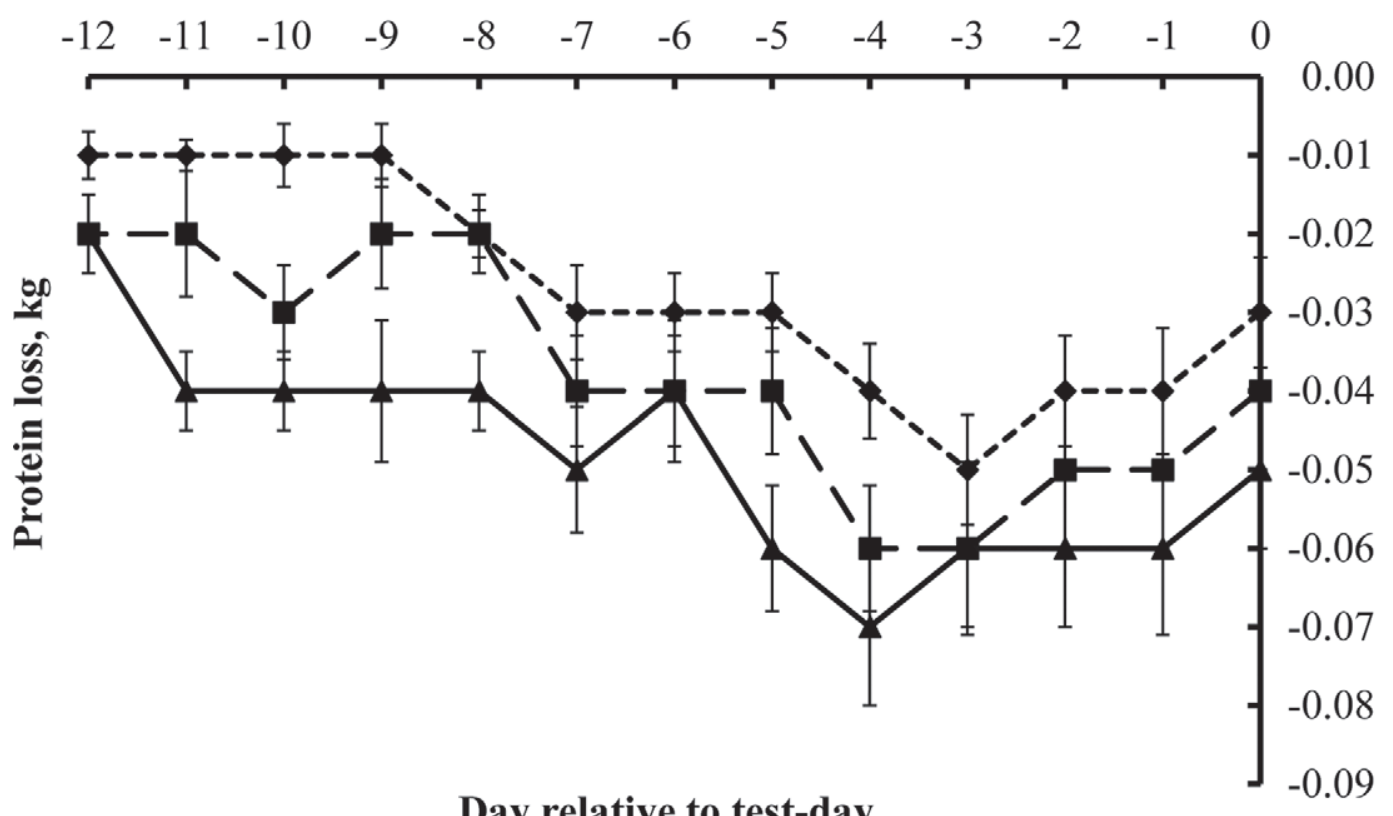

Figure 3. Effect and duration of temperature-humidity index (THI) stress on milk protein by parity [LSM ( \pm SD) loss pattern $(a$ : \%/d; b: $\mathrm{kg} / \mathrm{d})]$.

65 to 71 , and 72 to 73 for milk yield, protein percentage, and protein yield, respectively. Breaking points for the fat percentage were not detected in all parities, but breaking points for fat yield ranged from 71 to 72 . These THI values can be achieved with different temperature/humidity combinations. The THI from 65 to
76 can be obtained with a temperature range from 21 to $36^{\circ} \mathrm{C}$ and a relative humidity range from 5 to $95 \%$.

The threshold levels obtained in the present study were not always consistent with those reported by others. In fact, the thresholds are quite variable; for example, Johnson et al. (1962) reported a linear reduction 


\section{Day relative to test-day}

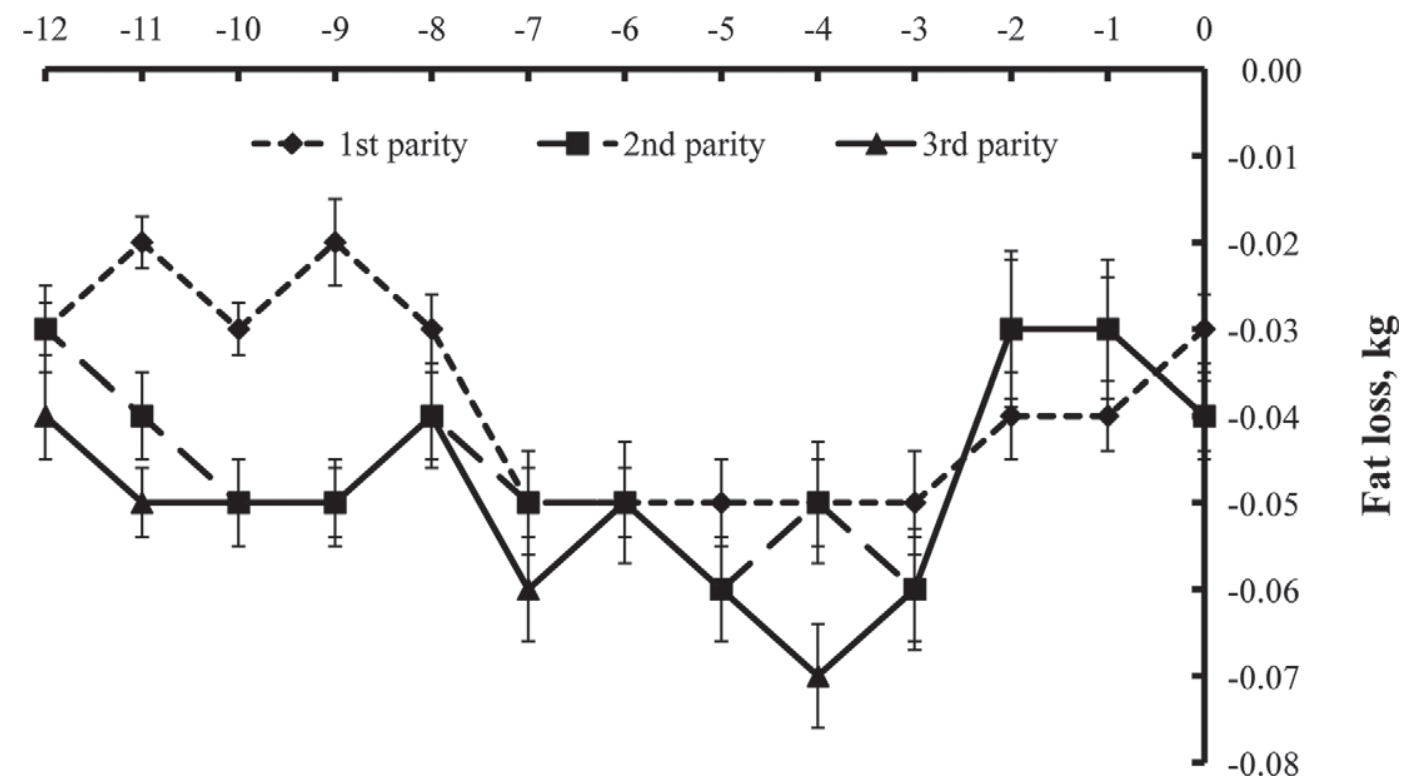

Figure 4. Effect and duration of temperature-humidity index (THI) stress on milk fat by parity [LSM ( \pm SD) loss pattern (kg/d)].

in milk yield when the THI exceeded 70. Ravagnolo et al. (2000) defined THI $=72$ as the threshold above which milk, fat, and protein yields started to decrease. Bouraoui et al. (2002) performed a 2-yr study, finding a negative correlation between milk yield and daily THI, with a decrease of $0.41 \mathrm{~kg}$ per cow per day for each THI unit increase above 69. Bohmanova et al. (2007) indicated a THI threshold of 72 in Georgia and 74 in Arizona. Bryant et al. (2007) reported patterns for fat and protein yield, with a decrease that occurred around the values of THI $=50$ and $\mathrm{THI}=60$, respectively, in New Zealand. Dikmen and Hansen (2009) reported a THI threshold of 78.2 in Florida. Brügemann et al. (2012) identified THI thresholds $=60$ and 70 for milk yield and no universally valid thresholds were identified for the fat and protein percentages in Lower Saxony (Germany). The observed variation threshold may have occurred because of the methods used for detecting the THI thresholds. In the current study, the THI threshold was actually the result of a 2-step process; first, a 2-phase regression was used to identify possible statistically significant breaking points along predefined intervals (i.e., a 16-d interval before milk recording) and second, a weighted average of the statistically significant breaking points ( 8 and $12 \mathrm{~d}$ before milk recording for milk yield and milk characteristics, respectively) was calculated for each trait. The idea behind this approach was as follows: (a) to detect possible breaking points using a more accurate methodology than graphical inspection that was easy to implement and (b) to account for the fact that the THI effect can be prolonged and not simply related to a peak observed during a particular day. In other words, considering only the THI on a particular day might lead to a biased estimate of its effect on production.

The THI thresholds found in this study remain greater than those obtained by some other authors (Bryant et al., 2007; Brügemann et al., 2012), and they are in line with thresholds found by others (Ravagnolo and

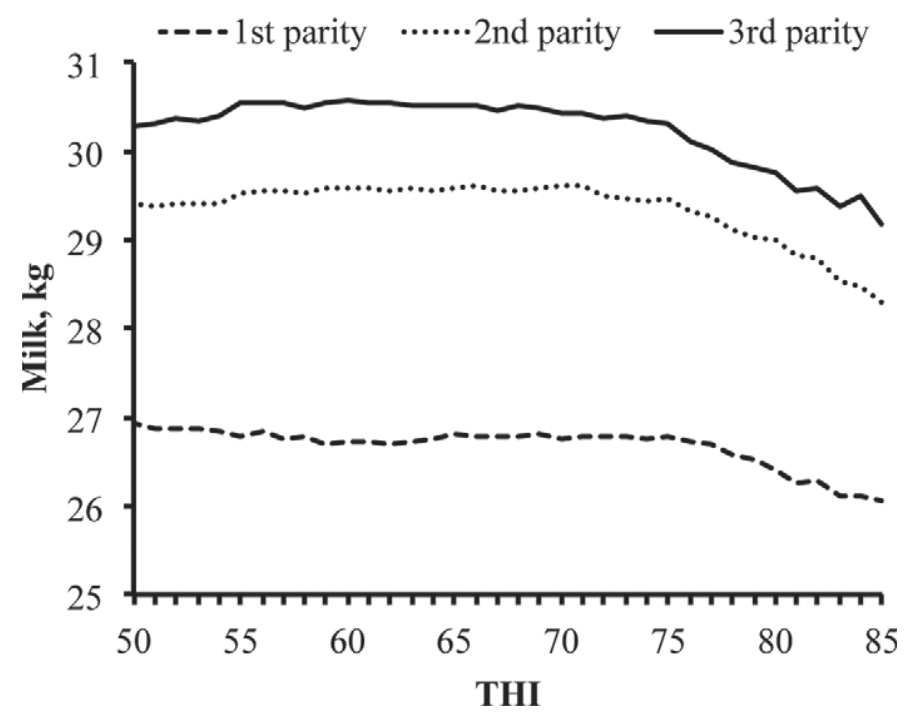

Figure 5. Least squared means for daily milk yield in the 3 parities adjusted for the effect of the temperature-humidity index (THI). 

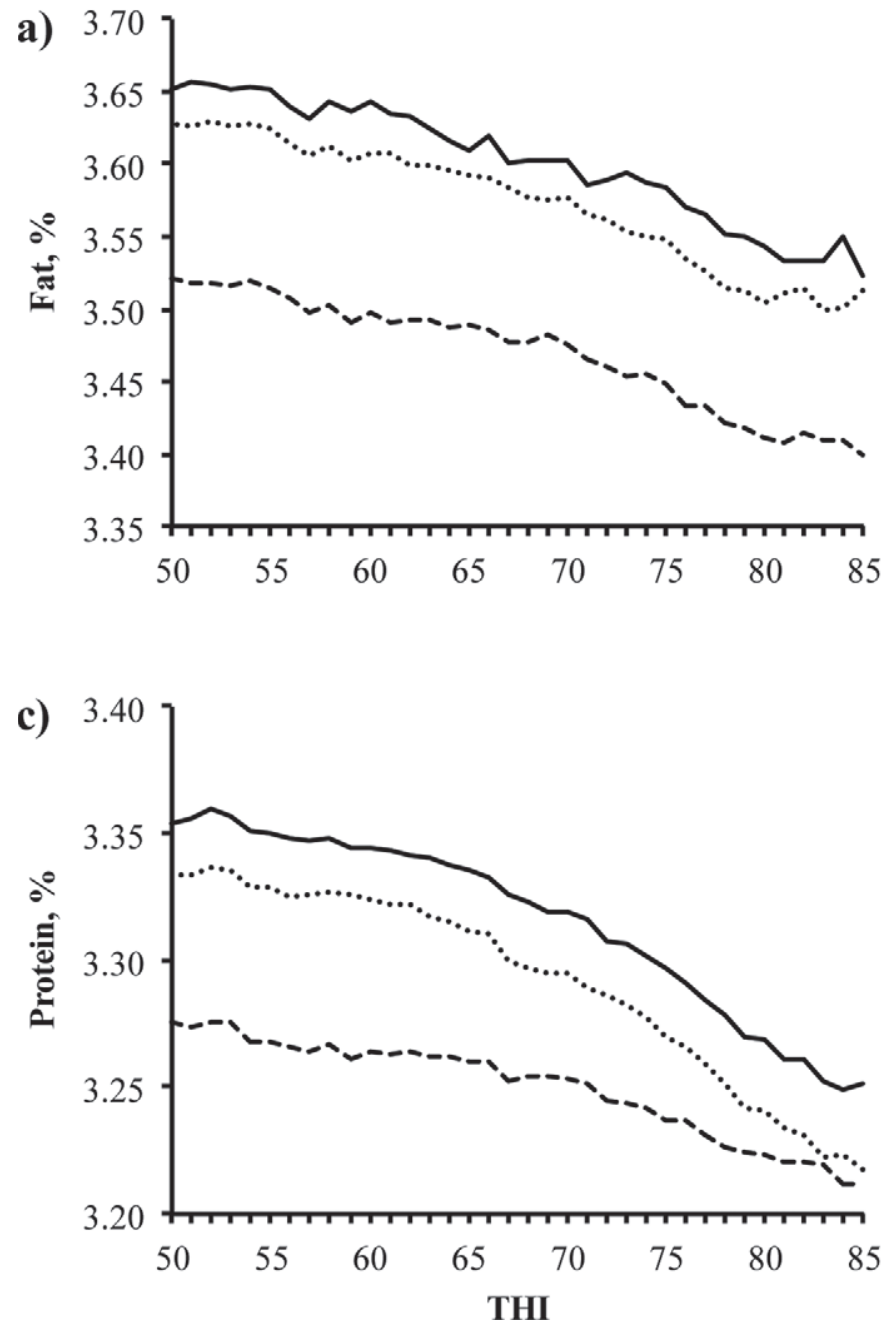
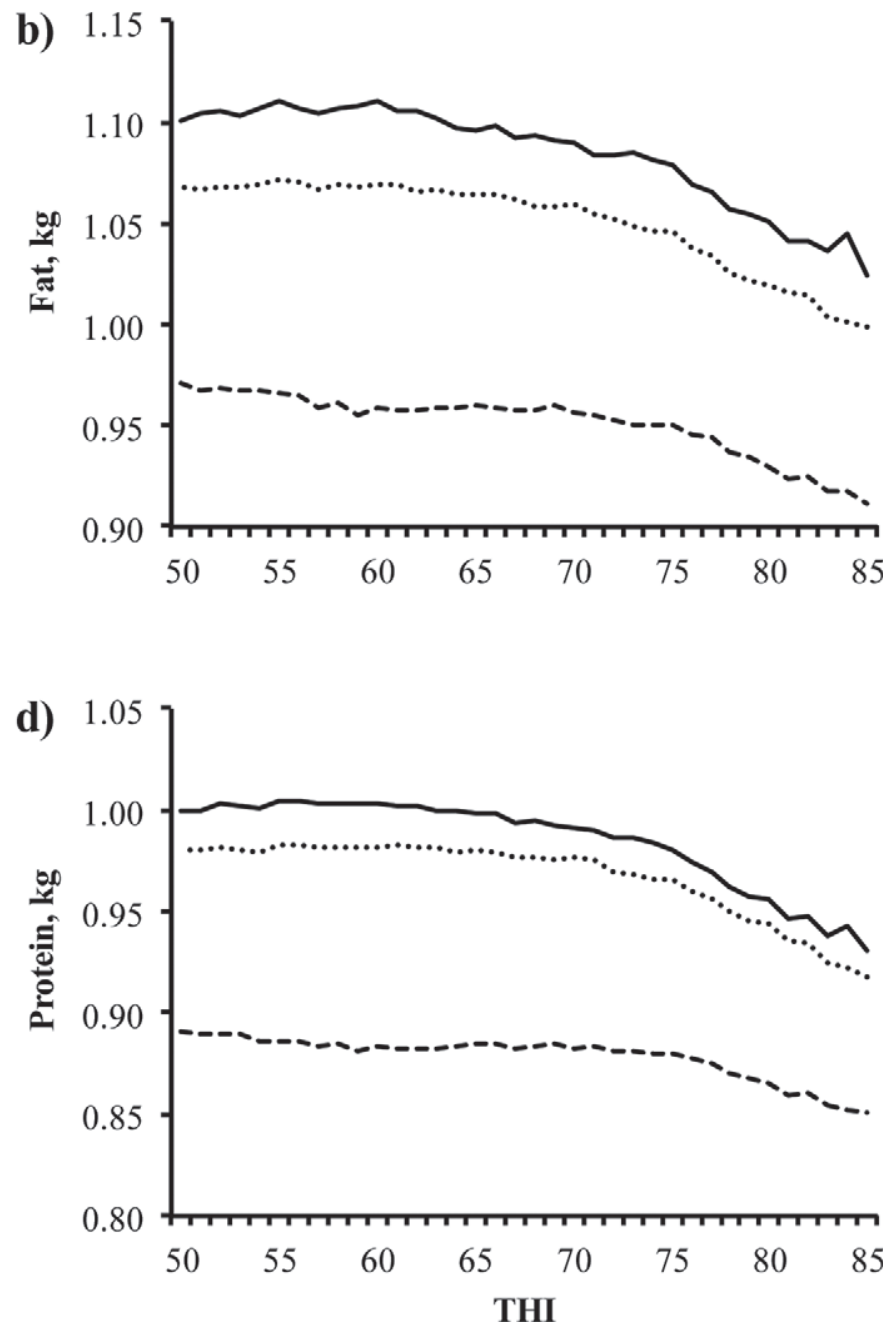

Figure 6. Least squared means adjusted for the effect of the temperature-humidity index (THI) for daily (a) fat percentage, (b) fat yield, (c) protein percentage, and (d) protein yield in the 3 parities.

Misztal, 2002a; Bohmanova et al., 2007; Dikmen and Hansen, 2009) who justified the high thresholds with better heat-adapted cows or by use of cooling facilities during hot seasons. It is well known that cooling systems have a very positive effect on alleviating the negative effects of high THI in dairy cattle (Collier et al., 2006). In the present study, 208 herds out of 484 $(43 \%)$ had no cooling systems, $179(37 \%)$ had fans, 8 $(1.6 \%)$ had sprinklers, and $89(18.4 \%)$ had both fans and sprinklers. The cooling effect was tested in model 1 and it was confounded with the herd effect, which was already fitted in the model.

The THI thresholds were not homogeneous across parities. In fact, the higher THI threshold for milk yield was found in primiparous cows compared with multiparous cows. This finding might be explained by considering that primiparous cows generate far less metabolic heat, have a greater surface area compared with internal body mass, produce less milk (Figure 5), and would be expected to suffer less from heat stress than mature cows (Armstrong, 1994; West, 1999, 2003; Aguilar et al., 2010a). In contrast, the first-lactation cows seem more sensitive to heat stress if the protein percentage is considered. This opposite response is not easy to explain. A possible hypothesis is that the firstlactation cows have higher protein needs than mature cows because other than milk protein yields, the firstlactation cows have to sustain their growth (Wathes et al., 2007). Furthermore, THI thresholds may also be affected by several environmental factors. It is important to carefully establish the THI threshold because it is a prerequisite for the correct estimation of heat tolerance 
Table 4. Summary of EBV without the inclusion of a temperature-humidity index (THI) covariate effect (EBV_M and EBV_PP), EBV including the THI covariate effect (EBV_Mw and EBV_PPw), and heat tolerance EBV (THI_M and THI_PP) calculated for each of the 8,859 sires for milk yield (M) and protein percentage (PP) traits

\begin{tabular}{lcc}
\hline Item & Range & Mean \pm SD \\
\hline Milk yield & & \\
EBV_M, kg/d & -3.1 to 9.1 & $0.89 \pm 1.26$ \\
EBV_Mw, kg/d & -4.6 to 10.7 & $0.93 \pm 1.45$ \\
THI_M, kg/d per THI unit $>76^{1}$ & -0.46 to 0.27 & $-0.017 \pm 0.062$ \\
Protein percentage & -36.8 to 43.5 & $0.38 \pm 8.80$ \\
EBV_PP, $\% \times 100 / d$ & -35.9 to 42.8 & $0.39 \pm 8.51$ \\
EBV_PPw, \% $\times 100 / d$ & -0.87 to 1.02 & $-0.006 \pm 0.170$ \\
THI_PP, $\% \times 100 / \mathrm{d}$ per THI unit $>65^{1}$ & & \\
\hline
\end{tabular}

${ }^{1}$ THI threshold (Table 1 ).

in dairy cattle (Sánchez et al., 2009), especially if the aim is the study of its genetic components (Aguilar et al., 2010b). In this respect, Sánchez et al. (2009) suggested modeling individual variations in milk yield decline to identify individual thresholds. Even if the results were positive, the same authors highlighted the problems related to the highly parameterized model structure, which makes the estimation procedure inefficient and the implementation onerous.

If we examine the effect of THI on production, we can clearly see that always 2 constant phases exist; that is, before the breaking point the production is constant and does not change. After the breaking point, production is affected and constantly decreases. In this situation, the fitting of 2 straight lines to the data points is a natural and justifiable choice. The 2-phase regression approach fits 2 different models before and after the hypothetical breaking point. If an actual change in production occurs, the slopes of the models will be different and the residual sum of squares will be smaller.

\section{Estimation of Additive Genetic Variance from the Heat Stress Effect}

Additive genetic variances on milk production traits from general and heat stress effects for the 3 parities were estimated by using a multiple-trait repeatability test-day model. Parameter values for production traits for the 3 parities are given in Tables 2 and 3. General additive genetic variance increased from the first to second parity and stayed stable from the second to third parity for milk yield, decreased slightly for protein percentage, and increased for fat and protein yield in all parities. Permanent environmental variances increased for all traits by approximately $100 \%$ from the first to the second parity and by approximately $30 \%$ from the second to the third parity. Residual variances were similar, increasing over parities. The values of the additive genetic variances by heat stress were estimated by using the weighted THI breaking points given in Table
1. Additive genetic variances for heat stress showed a 2 -fold increase from the first to second and from the second to third parity for milk, protein, and fat yield, and a 3-fold increase for protein percentage. Genetic correlations between general and heat tolerance effects were all negative and ranged from -0.24 to -0.56 . These data mean that milk production is antagonistic to heat tolerance and that the unfavorable effect is common to all parities and different traits. Additionally, permanent environmental correlations between heat stress and all traits were negative and ranged from -0.24 to -0.57 . General and heat stress heritability estimates decreased over parities for all traits, showing higher values in primiparous cows (Tables 2 and 3 ).

Estimates of the variance components for milk, fat, and protein yields were similar to those estimated by Freitas et al. (2006) for Holstein cows from different regions of the United States and by Aguilar et al. (2009) for dairy cows raised in Georgia (United States). Additive genetic effects for heat stress increased for all traits from first to third parity, and permanent environmental correlations were more negative from first to third parity for all traits except protein percentage. These results still confirm the higher sensitivity of multiparous cows to heat stress compared with primiparous individuals.

Negative genetic correlation estimates between production and heat stress in all parities for all traits observed in this study showed that selecting for higher milk, protein, and fat yield alone would lead to a decline in the genetic merit for heat tolerance, unless production level itself is used as a selection criterion in an aggregate index (Sánchez et al., 2009). It must be recalled that the total body heat load of lactating cows increases with the metabolic heat production associated with milk production and with the poor ability of cows to dissipate heat under hot conditions (Nardone et al., 2010). This heat aggravates the ability of highproducing dairy cows to maintain homeothermy under conditions of heat stress (Kadzere et al., 2002). Finally, considering that multiparous cows are genetically more 
Table 5. Bull ranking by using milk yield $(\mathrm{M} ; \mathrm{kg} / \mathrm{d})$ traditional breeding values [EBV_M; without the inclusion of the temperature-humidity index (THI)] or milk yield breeding values as estimated by including the THI (EBV_Mw) of the first 50 bulls

\begin{tabular}{|c|c|c|c|c|c|}
\hline Sire & EBV_M & $\operatorname{Rank}^{1}$ & EBV_Mw & Rankw $^{2}$ & THI_M ${ }^{3}$ \\
\hline S1 & 3.64 & 1 & 3.62 & 1 & -1.02 \\
\hline S2 & 2.72 & 2 & 2.77 & 3 & -2.86 \\
\hline S3 & 2.61 & 3 & 2.79 & 2 & -3.21 \\
\hline $\mathrm{S} 4$ & 2.58 & 4 & 2.59 & 5 & -0.72 \\
\hline S5 & 2.46 & 5 & 2.29 & 8 & -2.96 \\
\hline S6 & 2.45 & 6 & 2.69 & 4 & -0.35 \\
\hline S7 & 2.43 & 7 & 2.55 & 6 & -0.08 \\
\hline S8 & 2.42 & 8 & 2.12 & 10 & -1.29 \\
\hline S9 & 2.35 & 9 & 2.44 & 7 & -1.31 \\
\hline $\mathrm{S} 10$ & 2.05 & 10 & 2.15 & 9 & -2.66 \\
\hline S11 & 1.96 & 11 & 1.96 & 11 & -0.80 \\
\hline $\mathrm{S} 12$ & 1.88 & 12 & 1.69 & 14 & -0.59 \\
\hline $\mathrm{S} 13$ & 1.86 & 13 & 1.78 & 13 & -1.75 \\
\hline $\mathrm{S} 14$ & 1.76 & 14 & 1.59 & 17 & -1.90 \\
\hline $\mathrm{S} 15$ & 1.73 & 15 & 1.67 & 16 & 0.11 \\
\hline $\mathrm{S} 16$ & 1.70 & 16 & 1.49 & 23 & 0.40 \\
\hline $\mathrm{S} 17$ & 1.55 & 17 & 1.44 & 25 & 1.90 \\
\hline $\mathrm{S} 18$ & 1.55 & 18 & 1.88 & 12 & -1.74 \\
\hline S19 & 1.53 & 19 & 1.35 & 27 & -1.08 \\
\hline $\mathrm{S} 20$ & 1.52 & 20 & 1.55 & 19 & -2.75 \\
\hline $\mathrm{S} 21$ & 1.51 & 21 & 1.68 & 15 & 0.21 \\
\hline $\mathrm{S} 22$ & 1.48 & 22 & 1.24 & 30 & -0.34 \\
\hline $\mathrm{S} 23$ & 1.45 & 23 & 1.39 & 26 & -0.88 \\
\hline S24 & 1.44 & 24 & 1.54 & 20 & -0.90 \\
\hline $\mathrm{S} 25$ & 1.44 & 25 & 1.56 & 18 & -2.48 \\
\hline $\mathrm{S} 26$ & 1.38 & 26 & 1.53 & 21 & -0.82 \\
\hline $\mathrm{S} 27$ & 1.38 & 27 & 1.17 & 36 & -1.26 \\
\hline $\mathrm{S} 28$ & 1.37 & 28 & 1.31 & 28 & -1.44 \\
\hline S29 & 1.37 & 29 & 1.52 & 22 & -0.37 \\
\hline S30 & 1.36 & 30 & 1.12 & 39 & 0.08 \\
\hline S31 & 1.30 & 31 & 1.19 & 33 & 0.29 \\
\hline S32 & 1.26 & 32 & 1.28 & 29 & 0.13 \\
\hline S33 & 1.20 & 33 & 1.08 & 41 & -0.18 \\
\hline S34 & 1.20 & 34 & 1.15 & 38 & -1.33 \\
\hline S35 & 1.19 & 35 & 1.05 & 42 & -0.09 \\
\hline S36 & 1.17 & 36 & 1.17 & 34 & -0.54 \\
\hline S37 & 1.12 & 37 & 1.44 & 24 & -2.67 \\
\hline S38 & 1.11 & 38 & 1.17 & 37 & -1.82 \\
\hline S39 & 1.08 & 39 & 0.99 & 47 & -0.44 \\
\hline $\mathrm{S} 40$ & 1.08 & 40 & 1.01 & 45 & 1.25 \\
\hline S41 & 1.07 & 41 & 1.17 & 35 & -1.38 \\
\hline $\mathrm{S} 42$ & 1.02 & 42 & 1.01 & 46 & -0.87 \\
\hline S43 & 1.02 & 43 & 0.89 & 50 & 1.33 \\
\hline $\mathrm{S} 44$ & 1.02 & 44 & 0.46 & 82 & -0.17 \\
\hline S45 & 1.01 & 45 & 1.21 & 32 & -0.70 \\
\hline S46 & 1.01 & 46 & 1.22 & 31 & -0.19 \\
\hline S47 & 0.99 & 47 & 0.95 & 48 & -1.99 \\
\hline $\mathrm{S} 48$ & 0.98 & 48 & 1.09 & 40 & -1.58 \\
\hline S49 & 0.97 & 49 & 0.86 & 55 & -0.48 \\
\hline S50 & 0.94 & 50 & 0.72 & 59 & 0.99 \\
\hline
\end{tabular}

${ }^{1}$ Rank $=$ bulls ranked by EBV_M.

${ }^{2}$ Rankw $=$ bulls ranked by EBV_Mw.

${ }^{3}$ THI_M = milk yield heat tolerance EBV (kg/d per THI unit).

prone to heat effects, an aggregate index should be modulated to cope with this problem.

\section{Estimation of the EBV Including the THI Effect}

Three EBV per trait (milk yield and protein percentage) were calculated for each of the 8,859 sires, namely EBV_M and EBV_PP as estimated without the inclusion of a THI covariate effect, EBV_Mw and EBV_PPw as estimated including the THI covariate effect, and THI_M and THI_PP (heat tolerance EBV). The minimum, maximum, and mean values of each EBV are reported in Table 4 . The results indicate an increase in variability when THI is included in the EBV 
Table 6. Bull ranking by using protein percentage $(\% \times 100 / d)$ traditional breeding values [EBV_PP; without the inclusion of the temperature-humidity index (THI)] or protein percentage breeding values as estimated by including the THI (EBV_PPw) of the first 50 bulls

\begin{tabular}{|c|c|c|c|c|c|}
\hline Sire & EBV_PP & $\operatorname{Rank}^{1}$ & EBV_PPw & Rankw $^{2}$ & THI_PP ${ }^{3}$ \\
\hline S1 & 4.17 & 1 & 4.10 & 1 & -0.80 \\
\hline S2 & 3.55 & 2 & 3.36 & 2 & -0.58 \\
\hline S3 & 2.31 & 3 & 2.33 & 5 & -2.50 \\
\hline $\mathrm{S} 4$ & 2.23 & 4 & 2.35 & 3 & -2.08 \\
\hline S5 & 2.22 & 5 & 2.26 & 7 & -2.20 \\
\hline S6 & 2.17 & 6 & 2.31 & 6 & -2.72 \\
\hline S7 & 2.17 & 7 & 2.35 & 4 & -4.40 \\
\hline S8 & 2.03 & 8 & 1.91 & 11 & -0.60 \\
\hline S9 & 2.02 & 9 & 1.99 & 9 & -1.58 \\
\hline $\mathrm{S} 10$ & 1.99 & 10 & 2.00 & 8 & -0.34 \\
\hline S11 & 1.93 & 11 & 1.98 & 10 & -1.62 \\
\hline $\mathrm{S} 12$ & 1.81 & 12 & 1.78 & 12 & -1.11 \\
\hline $\mathrm{S} 13$ & 1.68 & 13 & 1.70 & 13 & -0.33 \\
\hline S14 & 1.59 & 14 & 1.54 & 15 & -0.33 \\
\hline $\mathrm{S} 15$ & 1.58 & 15 & 1.46 & 21 & 0.81 \\
\hline S16 & 1.56 & 16 & 1.56 & 14 & 0.06 \\
\hline S17 & 1.49 & 17 & 1.48 & 19 & -0.68 \\
\hline $\mathrm{S} 18$ & 1.48 & 18 & 1.45 & 23 & 0.29 \\
\hline S19 & 1.47 & 19 & 1.45 & 22 & -0.98 \\
\hline $\mathrm{S} 20$ & 1.47 & 20 & 1.49 & 18 & -1.71 \\
\hline S21 & 1.46 & 21 & 1.47 & 20 & -1.59 \\
\hline $\mathrm{S} 22$ & 1.46 & 22 & 1.44 & 24 & -0.31 \\
\hline $\mathrm{S} 23$ & 1.41 & 23 & 1.38 & 26 & -0.58 \\
\hline $\mathrm{S} 24$ & 1.41 & 24 & 1.54 & 16 & -1.68 \\
\hline $\mathrm{S} 25$ & 1.37 & 25 & 1.37 & 27 & -0.72 \\
\hline $\mathrm{S} 26$ & 1.34 & 26 & 1.51 & 17 & -1.85 \\
\hline $\mathrm{S} 27$ & 1.29 & 27 & 1.39 & 25 & -0.62 \\
\hline S28 & 1.26 & 28 & 1.26 & 30 & 0.09 \\
\hline S29 & 1.25 & 29 & 1.32 & 28 & -1.55 \\
\hline S30 & 1.21 & 30 & 1.04 & 36 & 0.83 \\
\hline S31 & 1.18 & 31 & 1.13 & 32 & 0.47 \\
\hline $\mathrm{S} 32$ & 1.13 & 32 & 1.32 & 29 & -2.47 \\
\hline S33 & 1.06 & 33 & 1.10 & 33 & -1.97 \\
\hline S34 & 1.06 & 34 & 1.14 & 31 & -1.98 \\
\hline S35 & 1.05 & 35 & 0.97 & 38 & -0.42 \\
\hline S36 & 1.04 & 36 & 1.01 & 37 & -0.01 \\
\hline S37 & 0.99 & 37 & 1.05 & 35 & -1.14 \\
\hline S38 & 0.94 & 38 & 0.91 & 40 & 0.14 \\
\hline S39 & 0.94 & 39 & 0.86 & 43 & 0.42 \\
\hline S40 & 0.92 & 40 & 1.08 & 34 & -2.87 \\
\hline S41 & 0.89 & 41 & 0.91 & 41 & -0.75 \\
\hline S42 & 0.86 & 42 & 0.96 & 39 & -0.40 \\
\hline $\mathrm{S} 43$ & 0.86 & 43 & 0.87 & 42 & -0.38 \\
\hline S44 & 0.82 & 44 & 0.83 & 44 & -0.39 \\
\hline $\mathrm{S} 45$ & 0.81 & 45 & 0.82 & 45 & -0.40 \\
\hline S46 & 0.81 & 46 & 0.78 & 48 & 0.27 \\
\hline S47 & 0.80 & 47 & 0.80 & 47 & -1.23 \\
\hline $\mathrm{S} 48$ & 0.78 & 48 & 0.80 & 46 & -0.66 \\
\hline S49 & 0.72 & 49 & 0.65 & 56 & 0.31 \\
\hline S50 & 0.72 & 50 & 0.76 & 49 & 0.41 \\
\hline
\end{tabular}

${ }^{1}$ Rank = bulls ranked by traditional EBV for milk yield estimated without the inclusion of the THI covariate effect.

${ }^{2}$ Rankw = bulls ranked by traditional EBV for milk yield estimated with the inclusion of the THI covariate effect.

${ }^{3}$ THI_PP $=$ protein percentage heat tolerance EBV $(\% \times 100 /$ d per THI unit $)$.

estimation of milk yield. In contrast, THI has no effect on the protein percentage of the EBV. In view of heat tolerance, the EBV mean value for both milk yield and protein percentage was negative, indicating and confirming the negative association between heat tolerance and milk production.
A total of 283 bulls were born after 1985 with at least 50 daughters. Comparing their rankings based on their EBV estimated with or without the inclusion of THI covariate effect, $17(6.23 \%)$ and $32(11.7 \%)$ bulls changed positions for milk yield and protein percentage values, respectively. The highest absolute position 


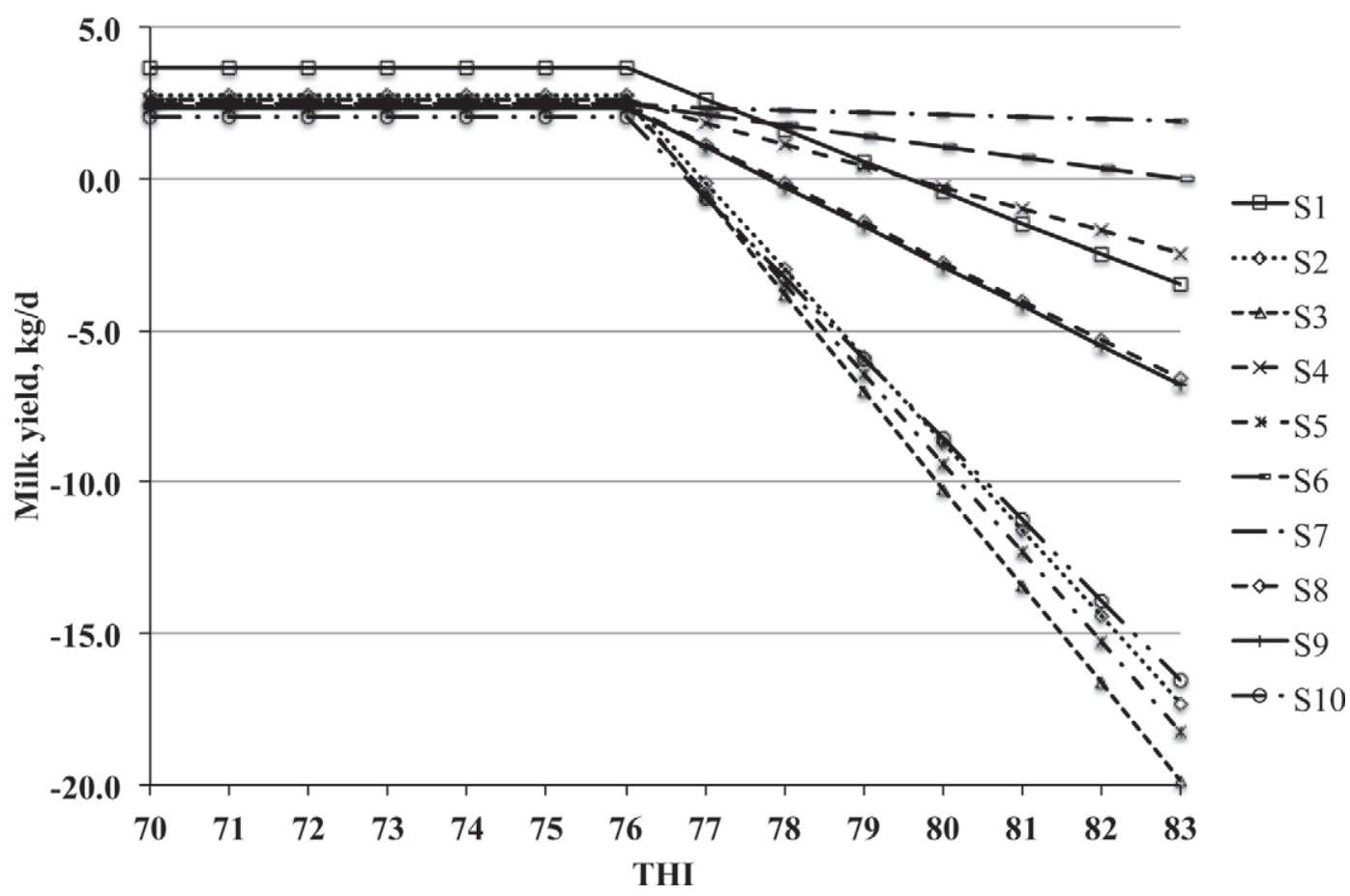

Figure 7. Prediction of sire EBV for milk yield as a function of the temperature-humidity index (THI) for the first 10 ranked bulls (see Table 5).

changes were 41 positions (from 204th to 163rd) for milk yield and 37 (from 125th to 88th) for protein percentage.

Traditional EBV, which were estimated with or without the effect of THI, and the heat tolerance EBV of the first 50 bulls, as well as their relative rankings, are reported in Tables 5 and 6 for milk yield and protein percentage, respectively. All EBV are expressed in genetic standard deviation units and bulls are ranked by using milk yield $(\mathrm{kg} / \mathrm{d})$ traditional breeding values (EBV_M) or milk yield breeding values (EBV_Mw), which were estimated by including the THI. Only 4 bulls out of 50 did not change in rank when THI was included in the estimation of milk EBV (Table 5), and the largest decrease was for bull S44, which lost 38 places. For the protein percentage (Table 6), 11 bulls out of 50 did not change their ranking when THI was included as a covariate effect. Bull S26 experienced the largest gain; it moved from rank 26 (EBV_PP) to rank 17 (EBV_PPw).

It would be interesting to consider THI in the estimation of EBV because the choice is usually made using the top 20 bulls. When THI was included in the estimation of milk EBV, bulls S16, S17, and S19 experienced the largest drop, moving from position 16 to 23,17 to 25 , and 19 to 27 , respectively (Table 5). Four bulls out of 20 sires did not change in rank when the THI was included in the estimation of protein EBV (Table
6). The other 16 sires changed in rank from position 1 to 6 (Table 6 ). For milk yield and protein percentage (Tables 5 and 6 ), 17 out of the 20 sires had a negative EBV for heat stress.

When THI is included in this model, it is possible to compare heat stress EBV among bulls as a function of THI. Bohmanova et al. (2008) investigated whether the differences in bull rankings from US regional genetic evaluations in the Southeast and the Northeast were caused by heat stress, and they observed no differences for heat stress in cooler and hotter regions for highreliability sires. The authors concluded that although some of the differences were accounted for by the heat stress effect in the model, most of those differences were not accounted for because of limitations in the model and the data. In contrast, Bryant et al. (2007) quantified the extent of within-breed sire reranking for milk production traits in a range of environments encountered within New Zealand. The authors observed some benefit in the environment-specific selection of sires in herds, which experienced low heat load indexes.

A comparison of heat tolerance EBV among bulls is especially interesting if the bulls have similar EBV when the THI effect is not considered (i.e., thermal-neutral conditions). Variability in the first 10 bulls' EBV for milk yield as a function of THI is shown in Figure 7. If a bull has a very negative heat stress EBV, his EBV for milk yield will decrease more as the THI increases 
(i.e., the bull is more genetically susceptible to the high temperature-humidity combination). Bull S1 had the highest EBV for milk yield and he still ranked fourth at THI $=83$. When the THI had no effect, bull S7 had an almost identical EBV to bull S8, but their respective EBV were extremely different as the THI increased.

Hayes et al. (2009) evaluated records on daughters from 798 sires to determine the degree to which milk yield was depressed by heat stress and found substantial variation between bulls. Heat tolerance is considered one of the most important adaptive aspects in cattle (Nardone and Valentini, 2000; McManus et al., 2009). In fact, the identification of heat-tolerant animals within high-producing breeds may be useful only if these animals are able to maintain high productivity and survivability when exposed to heat stress conditions (Gaughan et al., 2009). Bull S1 (Figure 7) is a good example of this type of condition. A heat tolerance index based on these measurements should be used to select bulls for thermotolerance.

\section{CONCLUSIONS}

This study represents the first comprehensive research about the effect of THI in Holstein cattle raised in the Mediterranean Basin. Our results confirm the negative effect of heat stress on dairy cattle performance reported in previous studies and demonstrate that the negative effects of high THI are more prolonged then the generally reported 2 to $4 \mathrm{~d}$. The extent to which milk production is affected varies among traits and parities. Multiparous cows are more susceptible to heat stress, and the decrease in milk yield can reach as much as $1 \mathrm{~kg} / \mathrm{d}$. These results might contribute to improved management (grouping strategies, fan-cooling systems, feeding and nutrition, and so on) of the dairy cattle herd in alleviating the negative effects of a hot environment. Selecting for heat tolerance is hampered by the negative (i.e., unfavorable) genetic correlation with milk production. However, the results of the present study demonstrate that the inclusion of THI covariate effects in the estimation of sire EBV changes the sire ranking; sires with the same genetic value (EBV) for milk production responded differently as the THI increased. Therefore, the inclusion of THI as a selection criterion in a selection index is recommended, especially for dairy cattle raised in hot environments in which profitability may continue to deteriorate over time.

\section{ACKNOWLEDGMENTS}

This study was supported by grants from Ministero delle Politiche Agricole, Alimentari e Forestali (Mipaaf,
Rome, Italy; CLIMANIMAL project, D.M. 306/7303/06 and FACCE-MACSUR project, D.M. 2660-20.06.2012).

\section{REFERENCES}

Aguilar, I., I. Misztal, and S. Tsuruta. 2009. Genetic components of heat stress for dairy cattle with multiple lactation. J. Dairy Sci. 92:5702-5711.

Aguilar, I., I. Misztal, and S. Tsuruta. 2010a. Genetic trends of milk yield under heat stress for US Holsteins. J. Dairy Sci. 93:17541758.

Aguilar, I., S. Tsuruta, and I. Misztal. 2010b. Computing options for multiple-trait test-day random regression models while accounting for heat tolerance. J. Anim. Breed. Genet. 127:235-241.

Armstrong, D. V. 1994. Heat stress interaction with shade and cooling. J. Dairy Sci. 77:2044-2050.

Berman, A. 2005. Estimates of heat stress relief needs for Holstein dairy cows. J. Anim. Sci. 83:1377-1384.

Bernabucci, U., N. Lacetera, L. H. Baumgard, R. P. Rhoads, B. Ronchi, and A. Nardone. 2010. Metabolic and hormonal acclimation to heat stress in domesticated ruminants. Animal 4:1167-1183.

Bohmanova, J., I. Misztal, and J. B. Cole. 2007. Temperature-humidity indices as indicators of milk production losses due to heat stress. J. Dairy Sci. 90:1947-1956.

Bohmanova, J., I. Misztal, S. Tsuruta, H. D. Norman, and T. J. Lawlor. 2008. Genotype by environment interaction due to heat stress. J. Dairy Sci. 91:840-846.

Bouraoui, R., M. Lahmar, A. Majdoub, M. Djemali, and R. Belyea. 2002. The relationship of temperature-humidity index with milk production of dairy cows in a Mediterranean climate. Anim. Res. 51:479-491.

Brügemann, K., E. Gernand, U. König von Borstel, and S. König. 2012. Defining and evaluating heat stress thresholds in different dairy cow production systems. Arch. Tierzucht 55:13-24.

Bryant, J. R., N. Lopez-Villalobos, J. E. Pryce, C. W. Holmes, D. L. Johnson, and D. J. Garrick. 2007. Environmental sensitivity in New Zealand dairy cattle. J. Dairy Sci. 90:1538-1547.

Collier, R. J., G. E. Dahl, and M. J. VanBaale. 2006. Major advances associated with environmental effects on dairy cattle. J. Dairy Sci. 89:1244-1253.

Collier, R. J., R. M. Eley, A. K. Sharma, R. M. Pereira, and D. E. Buffington. 1981. Shade management in subtropical environment for milk yield and composition in Holstein and Jersey cows. J. Dairy Sci. 64:844-849.

Dikmen, S., and P. J. Hansen. 2009. Is the temperature-humidity index the best indicator of heat stress in lactating dairy cows in a subtropical environment? J. Dairy Sci. 92:109-116.

du Preez, J. H., P. J. Hattingh, W. H. Giesecke, and B. E. Eisenberg. 1990. Heat stress in dairy cattle and other livestock under Southern African conditions. III. Monthly temperature-humidity index mean values and their significance in the performance of dairy cattle. Onderstepoort J. Vet. Res. 57:243-248.

Freitas, M., I. Misztal, J. Bohmanova, and R. Torres. 2006. Regional differences in heat stress in US Holsteins. Proc. 8th World Congr. Genet. Appl. Livest. Prod. Commun. 01-11. Istituto Prociencia, Belo Horizonte, Brazil.

Gaughan, J. B., N. Lacetera, S. E. Valtorta, H. H. Khalifa, L. Hahn, and T. Mader. 2009. Response of domestic animals to climate challenges. Pages 131-170 in Biometeorology of Adaptation to Climate Variability and Change. K. B. Ebi, I. Burton, and G. R. McGregor, ed. Springer Science, Heidelberg, Germany.

Hahn, G. L., T. L. Mader, and R. A. Eigenberg. 2003. Perspective on development of thermal indices for animal studies and management. EAAP Technical Series 7:31-44.

Hayes, B. J., P. J. Bowman, A. J. Chamberlain, K. Savin, C. P. van Tassell, T. S. Sonstegard, and M. E. Goddard. 2009. A validated genome wide association study to breed cattle adapted to an environment altered by climate change. PLoS ONE 4:e6676. 
Johnson, H. D. 1985. Physiological responses and productivity of cattle. Pages 4-19 in Stress Physiology in Livestock. Basic Principles. Vol. 1. M. K. Yousef, ed. CRC Press, Boca Raton, Florida.

Johnson, H. D., A. C. Ragsdale, I. L. Berry, and M. D. Shanklin. 1962. Effects of various temperature-humidity combinations on milk production of Holstein cattle. Research Bulletin No. 791. College of Agriculture, Agricultural Experimental Station, University of Missouri, Columbia.

Jordan, E. R. 2003. Effects of heat stress on reproduction. J. Dairy Sci. 86(E. Suppl.):E104-E114.

Kadzere, C. T., M. R. Murphy, N. Silanikove, and E. Maltz. 2002. Heat stress in lactating dairy cows: A review. Livest. Prod. Sci. 77:59-91.

McManus, C., E. Prescott, G. Paludo, E. Bianchini, H. Louvandini, and A. Mariante. 2009. Heat tolerance in naturalized Brazilian cattle breeds. Livest. Sci. 120:256-264.

Misztal, I., S. Tsuruta, T. Strabel, B. Auvray, T. Druet, and D. H. Lee. 2002. BLUPF90 and related programs. Commun. No. 28-07 in Proc. 7th World Congr. Genet. Appl. Livest. Prod. Montpellier, France.

Nardone, A., B. Ronchi, N. Lacetera, and U. Bernabucci. 2006. Climatic effects on productive traits in livestock. Vet. Res. Commun. 30(Suppl. 1):75-81.

Nardone, A., B. Ronchi, N. Lacetera, M. S. Ranieri, and U. Bernabucci. 2010. Effects of climate changes on animal production and sustainability of livestock systems. Livest. Sci. 130:57-69.

Nardone, A., and A. Valentini. 2000. The genetic improvement of dairy cows in warm climates. Proceedings of the joint ANPA-EAAPCIHEAM-FAO symposium on Livestock production and climatic uncertainty in the Mediterranean, Agadir, Morocco. EAAP Publication No. 94. European Federation of Animal Science (EEAP), Rome, Italy.

Nickerson, D. M., D. E. Facey, and G. D. Grossman. 1989. Estimating physiological thresholds with continuous two-phase regression. Physiol. Zool. 62:866-887.

NOAA (National Oceanic and Atmospheric Administration). 1976. Livestock hot weather stress. Oper. Man. Lett. C-31-76. Kansas City, MO. NOAA, Washington, DC.

Ravagnolo, O., and I. Misztal. 2000. Genetic component of heat stress in dairy cattle, parameter estimation. J. Dairy Sci. 83:2126-2130.

Ravagnolo, O., and I. Misztal. 2002a. Studies on genetics of heat tolerance in dairy cattle with reduced weather information via cluster analysis. J. Dairy Sci. 85:1586-1589.
Ravagnolo, O., and I. Misztal. 2002b. Effect of heat stress on nonreturn rate in Holstein cows: Genetic analysis. J. Dairy Sci 85:3092-3100.

Ravagnolo, O., I. Misztal, and G. Hoogenboom. 2000. Genetic component of heat stress in dairy cattle, development of heat index function. J. Dairy Sci. 83:2120-2125.

Sánchez, J. P., I. Misztal, I. Aguilar, B. Zumbach, and R. Rekaya 2009. Genetic determination of the onset of heat stress on daily milk production in the US Holstein cattle. J. Dairy Sci. 92:40354045

SAS Institute. 2002. SAS User's Guide: Statistics. Version 9.0. SAS Inst. Inc., Cary, NC.

Segnalini, M., A. Nardone, U. Bernabucci, A. Vitali, B. Ronchi, and N. Lacetera. 2011. Dynamics of the temperature-humidity index in the Mediterranean basin. Int. J. Biometeorol. 55:253-263.

Spiers, D. E., J. N. Spain, J. D. Sampson, and R. P. Rhoads. 2004. Use of physiological parameters to predict milk yield and feed intake in heat-stressed dairy cows. J. Therm. Biol. 29:759-764.

Vitali, A., M. Segnalini, L. Bertocchi, U. Bernabucci, A. Nardone, and N. Lacetera. 2009. Seasonal pattern of mortality and relationships between mortality and temperature-humidity index in dairy cows. J. Dairy Sci. 92:3781-3790.

Wathes, D. C., Z. Cheng, N. Bourne, V. J. Taylor, M. P. Coffey, and S. Brotherstone. 2007. Differences between primiparous and multiparous dairy cows in the inter-relationships between metabolic traits, milk yield and body condition score in the periparturient period. Domest. Anim. Endocrinol. 33:203-225.

West, J. W. 1999. Nutritional strategies for managing the heat-stressed dairy cows. J. Anim. Sci. 77:21-35.

West, J. W. 2003. Effects of heat-stress on production in dairy cattle. J. Dairy Sci. 86:2131-2144.

Zeileis, A., F. Leisch, K. Hornik, and C. Kleiber. 2002. strucchange: An $\mathrm{R}$ package for testing for structural change in linear regression models. J. Stat. Software 7:1-38.

Zimbelman, R. B., R. P. Rhoads, M. L. Rhoads, G. C. Duff, L. H. Baumgard, and R. J. Collier. 2009. A re-evaluation of the impact of temperature humidity index (THI) and black globe humidity index (BGHI) on milk production in high producing dairy cows. Pages 158-169 in Proceedings of the Southwest Nutrition Conference. R. J. Collier, ed. Accessed Feb. 2, 2009. http://cals.arizona. edu/ans/swnmc/Proceedings/2009/14Collier_09.pdf. 